\title{
LA ATENUANTE DE REPARACIÓN DEL DAÑO COMO INSTRUMENTO DE LA JUSTICIA RESTAURATIVA EN LA DELINCUENCIA SOCIOECONÓMICA*
}

\author{
María José Cuenca García**
}

Resumen: La revisión de los instrumentos penales a la luz de los postulados de la justicia restaurativa sitúa a la atenuante de reparación del daño en una posición central, en consideración a su directa conexión con la satisfacción de los intereses de la víctima. Desde este punto de vista, debe saludarse como especialmente atinente la objetivación de la atenuante que tiene lugar con la aprobación del Código penal de 1995, por la que se destierra el requisito del arrepentimiento espontáneo, y se facilita su aplicación al reo, con independencia de cuál sean los motivos de su actuación. Idéntico juicio favorable merece la ampliación del ámbito temporal de apli-

\section{Recibido: marzo 2020. Aceptado: julio 2020}

* Este trabajo se enmarca en el desarrollo del Proyecto I+D+I "Reparación, Justicia Restaurativa y Mediación en la delincuencia socioeconómica" (DER2017-84088-R).

** Prof. Agregada de Derecho penal. ORCID 0000-0003-0010-3205. Facultad de Derecho. Universidad Autónoma de Barcelona. Edificio B. Calle de la Vall Moronta, 08193. Bellaterra (Cerdanyola del Vallès). Barcelona. Email: mariajose.cuenca@uab.cat. 
cación, que se adelanta hasta el inicio de la fase del juicio oral. La contrapartida de esa objetivación radica en que la búsqueda a toda costa de la efectiva reparación del daño a la víctima podría provocar fricciones tanto con el ideal de la justicia restaurativa, como con los fines del Derecho penal. Lo primero, porque, puede llevar a la reparación sin diálogo con la víctima; lo segundo, porque cuando la reparación supone un esfuerzo insignificante para el autor, porque lo costea un tercero (el seguro, el coimputado o la persona jurídica) o porque por su especial poder económico no le deja mella, puede comprometer los fines de prevención general y especial. En estas coordenadas, la cuestión es si la actual configuración admite mejoras que maximicen el fin reparador sin afección al resto de cometidos del derecho penal, o si las mejoras deben y pueden proceder de una revisión de los criterios interpretativos a fin de librarlos de inercias históricas sin fundamento legal en la actualidad, y adecuarlos a las exigencias del nuevo modelo de justicia restaurativa. Para responder a esta cuestión parto de la actual configuración de la reparación como circunstancia atenuante, de la que pueden optimizarse sus posibilidades restaurativas sin tener que proponerla como tercera vía de respuesta al delito, en la senda de las versiones más estrictas del derecho premial sobre cuya intrínseca incompatibilidad con la esencia del derecho sancionador advierte Bricola. La especial gravedad de los delitos socioeconómicos que aquí se abordan, así como el peligro de que la mayor capacidad económica de sus autores inhiba el efecto intimidatorio que se espera del esfuerzo reparador me llevan a descartar la completa sustitución de la pena por la reparación como primera opción.

Palabras clave: justicia restaurativa, atenuantes, reparación del daño, victimología.

\title{
THE DAMAGE REPAIR AS MITIGATING CIRCUMSTANCE AND MEANS OF RESTORATIVE JUSTICE IN VIEW OF ECONOMIC CRIMES
}

\begin{abstract}
The revision of the criminal instruments in the light of the postulates of restorative justice places the mitigation of damage in a central position of the new model, in consideration of its direct connection with the satisfaction of the interests of the victim. From that point of view, the objective nature of the mitigating factor, which was introduced with the adoption of the 1995 Criminal Code, which abolishes the
\end{abstract}


requirement of spontaneous repentance and facilitates its application to the offender, regardless of the reasons for his action, is particularly noteworthy. The same favourable judgment is merited by the extension of the temporary scope of application, which is brought forward to the beginning of the oral proceedings phase. The counterpart of this objectivity is that the search for effective reparation of the harm to the victim at all costs could cause friction with both the ideal of restorative justice and the aims of criminal law. Firstly, because it can lead to reparation without dialogue with the victim; secondly, because when reparation involves an insignificant effort for the perpetrator, either because it is paid for by a third party the insurance company, the co-defendant or the legal entity), or because its special economic power does not leave a mark, it can compromise the aims of general and special prevention. In these coordinates, the question is whether the current configuration admits improvements that maximise the reparative end without affecting the rest of the criminal law tasks, or whether the improvements must and can come from a revision of the interpretative criteria in order to free them from historical inertias without a legal basis at present, and adapt them to the demands of the new model of restorative justice. To answer this question, I start from the current configuration of reparation as a mitigating circumstance, of which its restorative possibilities can be optimised without having to propose it as a third way of responding to the offence, in the path of the strictest versions of the Premial Law ,whose intrinsic incompatibility with the essence of the law of sanctions Bricola warns about. The special seriousness of the socio-economic crimes dealt with here, as well as the danger that the greater economic capacity of their perpetrators will inhibit the intimidating effect expected from the reparative effort, lead me to rule out the complete replacement of the penalty by reparation as the first option.

Keywords: restorative justice, mitigating factor, reparation of harm, victimology.

\section{Introducción}

La reparación del daño ocasionado a la víctima, tradicionalmente regulada entre las circunstancias atenuantes de la responsabilidad penal, cobra hoy un renovado protagonismo 
como instrumento de la justicia restaurativa, en consideración al papel central que concede a la víctima.

Otra cosa es que en su actual configuración e interpretación presente carencias para un modelo de justicia penal en el que no estaba pensando el legislador decimonónico al tiempo de su originaria formulación ${ }^{1}$, como tampoco pensaba en su proyección sobre los delitos socioeconómicos, prácticamente desconocidos en nuestro derecho histórico.

Desde estas premisas, a continuación, se describen los presupuestos aplicativos y problemas interpretativos de una institución que previsiblemente deberá adaptarse para cumplir con las exigencias de la justicia restaurativa ${ }^{2}$, de los que ya adelanto una observación y una reflexión.

Como observación general, debe destacarse que, como tendremos oportunidad de analizar detenidamente en este trabajo, su configuración legal en el Código penal de 1995 (epígrafe III.1) pero, sobre todo, su interpretación por parte de la jurisprudencia (epígrafe III.2), ha permitido que se haya aplicado de forma muy generosa a los sujetos que tienen gran solvencia y capacidad económica: los delincuentes socioeconómicos. Como veremos, ello se explica porque nuestros tribunales -alineados con las corrientes victimoló-

1 Me refiero al legislador decimonónico porque el primer Código en el que aparece es el de 1822, aunque luego desapareciera del catálogo de atenuantes hasta ser recuperada por el Código de 1928 para no volver a salir del mismo.

2 Sobre la discusión acerca de la misma como tercera vía, en la línea de Roxin, vid. GALAIN PALERMO, P., “¿La reparación del daño como "tercera vía" punitiva? Especial consideración a la posición de Claus Roxin", en Revista Electrónica de Derecho de la Universidad de la Rioja, núm. 3, 2005; Idem, La reparación del daño a la víctima del delito, Tirant lo Blanch, Valencia, 2010. Sobre la fricción entre los postulados tradicionales del Derecho penal y las nuevas corrientes restaurativas, por todos, BRICOLA, F., "Funzione promozionale, tecnica premiale e Diritto Penale", Diritto Premiale e Sistema Penale, Milano, 1983. Sobre las posibilidades de encaje de la reparación en nuestro sistema penal, por todos, ROXIN, C., "Pena y reparación", en ADPCP, Vol. LII, 1999. 
gicas- la han venido fundamentando exclusivamente en el aspecto objetivo de asegurar la satisfacción de los intereses de la víctima (epígrafe IV.1) comprometiendo la eficacia preventiva del derecho penal en este ámbito (epígrafe IV.2).

A partir de la anterior observación, en la última parte del trabajo formulo una propuesta alternativa de interpretación y aplicación de esta atenuante para los supuestos de delincuencia socioeconómica, reformulando el fundamento políticocriminal de la misma a fin de conciliar los intereses de la víctima con los fines preventivos propios del derecho penal (epígrafe V).

\section{Consideraciones generales sobre los efectos atenuantes de la conducta postdelictiva}

Con carácter previo al análisis detallado de la atenuante es preciso hacer mención a la filosofía que la inspira y que ineludiblemente se proyectará sobre su interpretación y aplicación. Como suele suceder, las aproximaciones teóricas a la figura son variadas, como también lo es la índole de las justificaciones posibles, si bien pero aquí todas parten de la común constatación de que la reparación del daño, en tanto que conducta postdelictiva, no puede alterar ni el contenido de injusto ni de culpabilidad personal respecto de un hecho previo.

Desde esa constatación, la idea del merecimiento de pena deja paso a la de necesidad de la pena ${ }^{3}$, que puede disminuir cuando se ha satisfecho a la víctima, y a partir de ahí se espigan diversas líneas de fundamentación de la atenuante.

Por un lado, un importante sector doctrinal ha destacado que, considerando la reparación de la víctima como un fin de la pena, ésta no sería necesaria cuando queda satisfecha de modo pronto y completo ${ }^{4}$. En esta línea, que podemos

3 Vid. por todos, el clásico trabajo de DE VICENTE REMESAL, J., El comportamiento postdelictivo, León, 1985, pp. 344-345.

4 POZUELO PÉREZ (El desistimiento en la tentativa y la conducta postdelictiva, Tirant monografías, Valencia, 2003, pp. 382-383) reconociendo 
considerar mayoritaria en la doctrina y la jurisprudencia, GARRO afirma contundentemente que "para favorecer a la víctima se asume la renuncia a una parte de la pena que se considera merecida y necesaria conforme a los objetivos de la responsabilidad penal"s.

La traducción práctica de este planteamiento ha sido la sistemática y generosa atenuación de la pena ante la objetiva reparación del daño, con incuestionables beneficios para los intereses de la víctima. El anverso de la moneda es la eventual discriminación de los reos sin capacidad económica.

Las críticas a esta práctica aplicativa no han tardado en llegar. Una auténtica perspectiva restaurativa -que reconozca a todas las partes del conflicto en términos de igualdad- es incompatible con la consideración de la reparación a la víctima exclusivamente desde un punto de vista objetivo. Debe compatibilizarse con el subjetivo, que lleva a tomar en consideración el esfuerzo reparador por parte del delincuente, sin olvidar lo más importante en derecho penal: la satisfacción de intereses sociales. En otras palabras, es necesario aunar en el acto reparador las pretensiones individuales de la víctima y el agresor, sin olvidar los otros agentes implicados en el conflicto, como la comunidad, que pueden cobrar especial relevancia en los delitos socioeconómicos ${ }^{6}$.

literalmente que, "en definitiva, el objetivo primordial es, efectivamente, la protección a la víctima $-\mathrm{O}$, más en general, al perjudicado por el delito-, que, como demuestra la práctica jurisprudencial, en escasas ocasiones ve satisfecho su derecho de crédito por responsabilidad civil como consecuencia de los daños sufridos".

5 GARRO CARRERA, E., Atenuantes de reparación y de confesión. Equívocos de la orientación utilitaria (A propósito de una controvertida sentencia del Juzgado de lo penal $n^{\circ} 8$ de Sevilla), Tirant monografías, Valencia, 2008, p. 23.

6 Con esta expresión me refiero a los delitos que afectan a bienes jurídicos de naturaleza colectiva, en el sentido de MARTÍNEZ-BUJÁN PÉREZ, C., en Pérez Álvarez (Ed.), "La expansión, la reducción y la legitimidad del Derecho penal económico", Serta in Memoriam Louk Hulsman, CISE-Ediciones Universidad de Salamanca, 2009, pp. 465 y ss. 
Por esta razón, otra línea doctrinal, ha defendido el efecto atenuante del acuerdo reparador en la menor necesidad de pena derivada de la colaboración con la Administración de justicia $^{7}$ o bien, -a mi juicio, con mayor acierto- de su contribución a la realización de los fines preventivo-generales positivos o integradores y preventivo -especial positivos ${ }^{8}$. En esta perspectiva, como se ha destacado ${ }^{9}$, los intereses individuales pueden aunarse con la satisfacción de los intereses colectivos y alinearse mejor con la perspectiva restaurativa que desarrollaremos más adelante ${ }^{10}$.

7 La menor necesidad de pena provendría del auxilio ofrecido a la justicia ahorrando actos procesales para conseguir pruebas incriminatorias o la ejecución de la responsabilidad civil, a pesar de que el responsable del hecho delictivo obre motivado por el único fin de beneficiarse de los efectos penológicos positivos que ofrecen estas circunstancias, y aunque en modo alguno se encuentre arrepentido por el hecho cometido. En esta línea se ha manifestado ALONSO FERNÁNDEZ, J. A., Las atenuantes de confesión de la infracción y reparación o disminución del daño, Bosch, Barcelona, 1999, pp. 24-25.

8 Vid. TAMARIT SUMALLA, J. M. a, "La justicia restaurativa: concepto, principios, investigación y marco teórico", en Tamarit Sumalla (Coord.), La justicia restaurativa: desarrollo y aplicaciones, Comares, Granada, 2012, p. 64. En el mismo sentido, SOLETO-GRANÉ ( $\mathrm{La}$ reparación económica de la víctima en el sistema de justicia, Dykinson, Madrid, 2019, p. 523) al señalar que "esa disposición por parte del autor del delito cumple con un claro propósito político-criminal hacia los fines de la pena, en tanto el comportamiento positivo del autor de reparar a la víctima cumple con las necesidades preventivo generales positivas (la asunción de responsabilidad por la conducta cometida) y preventivo especiales (al ser una clara política de favorecimiento de la víctima al promover la recuperación del bien jurídico)". Estas autoras van más allá, al señalar que con la reparación del daño se liberará "a la Administración de Justicia en lo relativo al trámite del abono de la responsabilidad civil derivada de delito, en el caso de que la hubiera".

9 GARCÍA SOLÉ, M./MARTÍ GARCIA-MILÀ, N., "Justicia restaurativa: la circunstancia atenuante del art. 21.5 CP de reparación del daño ocasionado a la víctima", en Lluch, A. (Coord.), Las medidas preventivas de conflictos jurídicos en contextos económicos inestables, Bosch, Barcelona, 2014, p. 113.

10 Vid. supra epígrafe V. 


\section{Regulación legal y criterios de aplicación jurispruden- cial de la atenuante de reparación del daño}

Con carácter previo a extraer conclusiones de esta atenuante en el contexto de la delincuencia socioeconómica, me parece imprescindible, en primer lugar, apuntar las principales características de su configuración legal y, sobre todo, cuál ha sido la interpretación y aplicación que ha venido realizando la jurisprudencia.

\section{Configuración legal}

$\mathrm{El}$ art. $21.5^{\mathrm{a}} \mathrm{CP}$ declara que es circunstancia atenuante de la responsabilidad penal "haber procedido el culpable a reparar el daño ocasionado a la víctima, o disminuir sus efectos, en cualquier momento del procedimiento y con anterioridad a la celebración del acto del juicio oral".

\subsection{La objetivación de la atenuante}

La actual configuración de la atenuante no coincide con la de sus precedentes históricos, marcados por el sentido expiatorio que le imprime el Código de 1822, que con el tiempo pervivirá en los requisitos de voluntariedad y espontaneidad y la consiguiente limitación temporal de su ámbito aplicativo ${ }^{11}$.

11 El CP de 1822 condiciona la aplicación de la atenuante al arrepentimiento y la enmienda; el CP de 1928 exige espontaneidad, inmediatez y propio sacrificio personal o económico, además de introducir un límite temporal máximo, que queda fijado por el principio del procedimiento penal; el CP de 1932 recupera el componente de arrepentimiento del CP de 1982, manteniendo la espontaneidad del CP de 1928, y ampliando el límite máximo hasta el momento en el que el acusado conoce la apertura del procedimiento judicial; el CP de 1944 mantiene la configuración inmediatamente antecedente, con un significativo detalle diferencial y es que trata de culpable al autor de la reparación, cuando es necesariamente previa al juicio, lo que es especialmente sintomático del valor que en ese momento histórico se concedía a la confesión del culpable. Al respecto, vid. BARJA DE QUIROGA / RODRÍGUEZ RAMOS / RUIZ DE GORDEJUELA LÓPEZ, Códigos penales españoles 18221848-1850-1870-1928-1932-1944. Recopilación y concordancias, Akal, Madrid, 1988. 
Frente a esa tradición histórica, el Código actual opta por la objetivación de la atenuante y la relativa extensión de su ámbito aplicativo, como modo de promover la satisfacción de la víctima, que se entiende que no puede quedar postergada por la falta de contrición moral del autor.

Con este fin, el legislador de 1995 modificó radicalmente las condiciones aplicativas de una circunstancia atenuante que hasta la fecha se había fundado en el "arrepentimiento espontáneo"12 al que todavía aludía el Código de 1973, al exigir "haber procedido el culpable antes de conocer la apertura del procedimiento judicial, y por impulsos de arrepentimiento espontáneo, a reparar o disminuir los efectos del delito, a dar satisfacción al ofendido o a confesar a las autoridades la infracción". Así las cosas, no puede extrañar que la jurisprudencia supeditara su aplicación a la comprobación del arrepentimiento moral plasmado en "sentimientos de pesar, aflicción o constricción por la perpetración del hecho delictivo, dolorido en su fuero íntimo"13.

Para un "código penal de la democracia una tal concepción moral de la atenuante debía ser modificada por una configuración más objetiva en la que primaba el comportamiento externo reparador y no el arrepentimiento" 14 . Como señala TAMARIT, la atenuante debía refundarse a partir de "razo-

12 Vid. TAMARIT SUMALLA, J. M. a, "La difícil asunción de la reparación penal por parte de la jurisprudencia española", en Revista General de Derecho Penal, núm. 7, 2007, p. 4.

13 Vid., en este sentido literalmente, la STS de 15 de mayo de 1989.

14 En realidad, el legislador de 1995 asumía así la moderna jurisprudencia que aplicó el código franquista en la incipiente democracia de los años ochenta. Vid., por ejemplo, STS de 7 de noviembre de 1989 o STS de 20 de febrero 1987: "el pesar del autor por haber obrado mal, su contrición tiene un excepcional valor ético, pero, es evidente que en el ámbito jurídico hoy no es ya exigible. Para la apreciación de la atenuante basta, como esta Sala ha subrayado la sustitución de la voluntad antijurídica por la voluntad de realizar actos de cooperación a los fines del ordenamiento jurídico". 
nes utilitarias o de política criminal relacionadas con la voluntad legal de favorecer la situación de la víctima"15.

En esa senda de objetivización de la atenuante, el primer paso fue la división en dos de aquello que, desde el Código de $1932^{16}$, había unido en el común sentimiento de arrepentimiento: la confesión y la reparación, que en la actualidad dan pie a dos circunstancias autónomas, y, por lo tanto, acumulables.

Así, donde antes hubiera una sola atenuante (art. 9.9 CP 1973), hoy hallamos dos, sitas en el art. $21,4^{\text {a }}$ y $5^{\text {a }} C P$ 1995 , cuyo componente subjetivo nada tiene que ver con el que tradicionalmente la había definido. El componente subjetivo de la nueva atenuante de confesión del art. 21. $4^{\mathrm{a}} \mathrm{CP}$, se limita al voluntario reconocimiento de los hechos como modo de colaboración con la Administración de Justicia, completamente despojado de cualquier dimensión moral; mientras que la atenuante de reparación del daño tiene como misión principal la objetiva satisfacción de la víctima ${ }^{17}$,

15 TAMARIT SUMALLA, "La difícil asunción (...)”, ob.cit., p. 4. Así lo recoge la STS de 18 de abril de 2003 al señalar que esta circunstancia atenuante supone "una típica decisión de política criminal del legislador, en la que ha primado la consideración del beneficio objetivo de la víctima - sea por la vía de la plena reparación de los daños sufridos por la misma, sea por la mera disminución de sus efectos-sobre los aspectos éticos y subjetivos propios de las razones que hayan podido determinar al culpable a actuar de tal manera tras la comisión del hecho punible". Vid., en el mismo sentido, STS de 29 de abril de 2005.

16 Como se recordará, en el Código de 1928, la reparación y la confesión habían constituido atenuantes autónomas (art. 64, $6^{\mathrm{a}}$ y $7^{\mathrm{a}}$, respectivamente).

17 Con todo, el hecho de que en la actualidad se prime la objetiva satisfacción de la víctima no significa que sea irrelevante la presencia de cierto componente subjetivo. En este sentido se pronuncia la reciente STS 272/2020, de 6 de febrero, al recordar que para poder apreciar esta atenuante la reparación debe ser voluntaria. Así, señala que resultará "conveniente primar a quien se comporta de una manera que satisface el interés general, pues la protección de los intereses de las víctimas no se considera ya como una cuestión estrictamente privada, de responsabilidad 
aunque limitada al respeto de un límite temporal máximo en el que se concentran las principales trabas a la consecución de los fines de la justicia restaurativa.

Desde estas premisas no es de extrañar que el Tribunal Supremo insista en que "no importa que el acusado esté o no arrepentido, no importan tampoco los móviles, lo determinante es reparar en la medida de lo posible el daño ocasionado a la tan olvidada víctima" ${ }^{18}$. Consecuentemente con ello, como tantas veces sucede en las causas por delitos económicos, la atenuante se aprecia aun cuando consta que el único fin es el de conseguir el beneficio penológico del que el acusado tiene noticia por vía de su abogado ${ }^{19}$.

civil, sino como un interés de toda la comunidad. Pero esta colaboración del autor de los hechos a la reparación del daño ha de ser voluntaria, de modo que, por mucha objetivización que se pretenda dar a la atenuante no puede admitirse cuando, por ejemplo, se satisface la indemnización por requerimiento judicial vía arts. 589 y 783.2 LECrim".

18 Vid. STS de 22 de septiembre de 2004. Se ha advertido que en la jurisprudencia existe una línea minoritaria que fundamenta la atenuante, no en la protección objetiva a la víctima, sino en la doctrina del "actus contrarius". Pero incluso en estos casos donde se precisa el reconocimiento, por parte del autor, de la infracción de las normas, puntualiza que "no es el reconocimiento expreso de la culpabilidad el requisito necesario para aplicar la atenuante, sino que lo es la reparación efectiva del daño en que consiste ese actus contrarius". Vid. STS de 3 de octubre de 2003, citada por MAGRO SERVET, V., "Doctrina jurisprudencial reciente del Tribunal Supremo sobre la atenuante de reparación del daño (art. 21.5 CP)", en La Ley penal, núm. 50, 2008, p. 4. Vid. STS 9 de abril de 2001 y 29 de abril de 2005, citadas por TAMARIT SUMALLA, "La difícil asunción (...)", ob.cit., p. 5. GARRO CARRERA (Atenuantes de reparación (...), ob.cit., p. 51) destaca que, "si la reparación penal se conceptuase como un actus contrarius respecto del delito, se deduciría que su relevancia penal debería residir en la menor necesidad de pena que derivaría de los actos reparadores, puesto que el infractor, mediante su conducta postdelictiva, estaría ya cumpliendo, al menos en parte, con el fin de reafirmación de la vigencia del ordenamiento jurídico que se asigna a la sanción".

19 Esta interpretación empezó incluso a defenderse por la jurisprudencia en los primeros años 90 en vigencia del anterior código penal. Vid. STS de 27 de mayo de 1992, que estableció que "el requisito subjetivo, el móvil de dicho comportamiento, tanto puede ser el pesar de haber obrado mal, 


\subsection{La ampliación del ámbito de aplicación temporal}

Continuando con las condiciones aplicativas de la atenuante, debe hacerse especial mención a la extensión de su ámbito de aplicación temporal, así mismo orientado a promover la reparación del daño. Desde 1995, cabe la reparación más allá del "conocimiento de la apertura del procedimiento judicial", siempre que tenga lugar "con anterioridad a la celebración del acto del juicio oral".

La ampliación del ámbito aplicativo de la atenuante supone que la reparación puede verificarse una vez presentados los escritos de calificación ${ }^{20}$, con la correspondiente propuesta de medios probatorios, entre los que no constarían los relativos a una reparación todavía no efectuada. Así y todo, ello no supone el estrangulamiento de las posibilidades procesales de solicitar la aplicación de la atenuante, toda vez que al inicio de las sesiones del juicio oral las partes pueden solicitar nuevos medios de prueba ${ }^{21}$, entre los que pueden incluirse los relativos a la reparación satisfecha tras la presentación de los escritos de calificación provisional. La posibilidad de invocación de nuevos medios de prueba en este momento procesal no es ilimitada, y se somete a la condición de que no hayan podido ser propuestos con anterioridad ${ }^{22}$,

como el temor a la pena, que trata de atenuarse en su propio beneficio, estimándose, además, que la espontaneidad se considera compatible con la concurrencia de consejos o sugerencias". Sin embargo, como señala GARRO CARRERA (Atenuantes de reparación (...), ob.cit., pp. 56-57), la conducta reparadora presupone que el infractor se involucre personalmente en la misma, y ello, "no sólo para descartar que la reparación no haya sido coaccionada, sino para asegurar que sea el infractor quien despliega una conducta dirigida a lograr esa compensación del daño ocasionado".

20 Vid. arts. 650 y ss. LECrim.

21 Vid., por ejemplo, art. 729 LECrim, para los procesos ordinarios, y art. 786.2 LECrim, para el proceso abreviado.

22 Acerca del inicio de la fase de juicio oral, vid. MORALES PRATS, F. y BERTOLÍN PONSA, E., "Juicio oral (I): artículos de previo pronunciamiento, cuestiones previas e inicio del juicio oral”, en Cugat Mauri/ 
pero ello es precisamente lo que sucede cuando la reparación tiene lugar tras la presentación de los escritos de calificación.

De manera que, del tenor literal del art. $21.5^{\text {a }} \mathrm{CP}$ se desprende que la reparación puede realizarse durante toda la fase de instrucción e incluso tras la apertura de las sesiones del juicio oral. Es más, según algún autor (SOTO NIETO ${ }^{23}$ ) y alguna sentencia (STS 16-3-2006), podría incluso realizarse durante todas las sesiones del juicio oral o incluso tras ellas.

A la expresa ampliación del ámbito aplicativo de la atenuante de reparación regulada en el art. 21.5 $\mathrm{CP}$ debe añadirse la posibilidad de aplicación de la atenuante de análoga significación del art. 21.7 $\mathrm{CP}$, que se ha invocado para reconocer efectos atenuantes a la reparación del daño producida una vez iniciadas las sesiones del juicio oral. De este modo, aunque la reparación realizada durante el transcurso de las sesiones del plenario quede fuera de las previsiones literales del legislador, según las circunstancias del caso puede dar lugar a una atenuante analógica ${ }^{24}$. Es más, bajo

Baucells Lladós/Aguilar Roma, Manual de litigación penal, Tirant lo Blanch, Valencia, 2017, pp. 331 y ss. Sobre la proposición de prueba en los escritos de calificación y la posibilidad de proponer prueba al inicio de las sesiones del juicio oral, vid., entre otros, RAMOS MENDEZ, F., Enjuiciamiento Criminal. Duodécima lectura constitucional, Atelier, Barcelona, 2016, pp. 377 y ss.; ARMENTA DEU, T., Lecciones de derecho procesal penal, Marcial Pons, Madrid, 2017, pp. 283 y ss.; y LÓPEZ FONDÓN, P. y HERNÁNDEZ GARCÍA, J., "Juicio oral (II): práctica y valoración de la prueba”, en Cugat Mauri/ Baucells Lladós/Aguilar Roma, Manual de litigación penal, Tirant lo Blanch, Valencia, 2017, pp. 343 y ss.

23 SOTO NIETO, F., "Atenuante de reparación o disminución de los efectos del delito", en Diario La Ley, núm. 6609, 2006, p. 3.

24 Así, STS 744/2000, de 4 de febrero. Procesalmente, la reparación del art. $21.5^{\mathrm{a}}$ podrá aplicarse hasta que se pueda introducir prueba acreditativa de la realidad de dicha reparación, es decir, una vez iniciado el juicio oral, y antes de proceder a la práctica de la prueba, pues sólo así la actividad reparadora y su prueba habrán estado sometidas al debate y contradicción necesaria que puedan justificar la aplicación de una atenuante (en este sentido, DE LA HERRÁN, S., "Aspectos técnicos de la atenuante de reparación del daño en los delitos económicos o de 
el concepto de "reparación tardía" algunas resoluciones han llegado a aplicar la atenuante incluso cuando la reparación tiene lugar después del juicio oral y antes de la sentencia ${ }^{25}$, en especial, en supuestos especialmente alejados del arrepentimiento espontáneo, como son aquellos en los que la decisión de reparación se produce tras la constatación de las exiguas posibilidades de absolución a la vista del desarrollo de las sesiones de la vista oral.

\subsection{El alcance material de la reparación}

Continuando con la relación de elementos legales de la atenuante, es preciso hacer mención a la entidad material de la reparación.

Como es lógico, esta debe tener cierta entidad, y así se recoge en la jurisprudencia del Tribunal Supremo, según la que sólo es aplicable cuando la reparación del daño "es suficientemente significativa y relevante", en consecuencia, no tendrán efecto atenuatorio las acciones fácticas que lo que pretenden es buscar una menor respuesta punitiva "sin contribuir de modo eficiente y significativa a la efectiva reparación del daño ocasionado"”26. Otra cosa, sobre la que volveré luego, es que en la valoración de la entidad de la reparación deba darse entrada a la consideración al esfuerzo reparador, que nos lleva a alejarnos de criterios cuantitativos absolutos y mucho más de la aplicación mecánica de cualquiera de ellos.

cuello blanco", en Revista penal, núm. 45, 2020, p. 20). A partir de este momento, deberá considerarse una aplicación analógica del art. 21.7 CP. En la misma línea, SOTO NIETO, ult.ob.cit., p. 3 y, GARCÍA SAN MARTÍN, J., "La reparación del daño como circunstancia modificativa de la responsabilidad criminal", en Revista de Derecho Penal, núm. 32, 2011, pp. 96 y ss.

25 Vid. STS de 30 de octubre de 1991 o STS de 8 de noviembre de 1995. Entre la doctrina, a favor, DE VICENTE MARTÍNEZ, R., "Circunstancias de la responsabilidad criminal", en Demetrio Crespo, E. (Coord.), Lecciones y materiales para el estudio de Derecho penal, Tomo II, Teoría del delito, Iustel, Madrid, 2015, p. 403.

26 Vid. STS 272/2020, de 6 de febrero y, STS 544/2016, de 21 de junio, entre otras. 
En línea con sus precedentes históricos, el código penal de 1995 otorga efectos atenuantes tanto a la reparación total ("reparar el daño ocasionado a la víctima") como la parcial ("o disminuir sus efectos"). Esto es, tanto la que consigue el retorno al estado previo al delito, como la que lo consigue solo en parte.

A su luz, la jurisprudencia aplica el límite mínimo del marco penal tanto cuando la reparación del daño es total como parcial ${ }^{27}$, siempre que en esta se aprecie la voluntad reparadora, mediante la que se reequilibran las posibles desigualdades en la situación económica del responsable penal. Como recoge TAMARIT "la idea de esfuerzo reparador no queda así del todo olvidada "28.

El problema que presentan los delitos socioeconómicos tiene que ver con la dificultad de conocer la cuantía del daño social causado, que en muchos casos será "incuantificable", lo que podría disminuir sus posibilidades aplicativas $^{29}$. Como ha avanzado algún autor, en estos casos "es indiscutible la necesidad de apreciar la atenuante exclusivamente en su extensión parcial o disminuida, ya que en ningún caso es posible retornar al mismo estado las cosas existentes antes de la perpetración del hecho delictivo por su afección a múltiples aspectos de la economía y la sociedad" ${ }^{\prime 30}$. En estos

27 Vid. STS de 24 de enero de 2003, STS de 13 de mayo de 2004, STS de 22 de junio de 2005, STS de 20 de junio de 2007 o, STS 272/2020, de 6 de febrero, entre muchas otras.

28 TAMARIT SUMALLA, "La difícil asunción (...)", ob.cit., p. 7.

29 Una propuesta reciente de definición del daño social en la delincuencia económica puede encontrarse en CASTRO, D./BONSIGNORE, D., "Delincuencia socioeconómica y daño social. Perspectivas político-criminales para un contexto poscrisis", en Estudios Penales y Criminológicos, núm. 40, 2020, pp. 45 a 111.

30 DE LA HERRÁN, ("Aspectos técnicos de la atenuante (...)", ob.cit., p. 23), después de señalar que "si asumimos que ninguna actividad post delictual destinada al resarcimiento pueda subsanar los daños ya ocasionados, parece lógico estimar que en el seno de la delincuencia económica no se podrá apreciar una reparación total o absoluta, sino 
supuestos la pena resultante debería acercarse a la mitad del marco abstracto previsto para el tipo penal.

\subsection{La víctima como destinataria de la reparación}

El carácter aparentemente expansivo de la atenuante queda desdicho en un único punto, que tiene que ver con el beneficiario de la reparación, toda vez que el artículo $21.5^{\mathrm{a}} \mathrm{CP}$ exige ahora que se repare el daño "ocasionado a la víctima", por contraste con la redacción del Código inmediatamente anterior que se refería al "ofendido".

De modo que, el código vigente -que podía haber utilizado cualquier otra expresión ("ofendido", "perjudicado", etc.)- utiliza el concepto de "víctima", como persona sobre quien recae el comportamiento delictivo y no necesariamente el sujeto pasivo o titular del bien jurídico afectado. Por esta vía se da entrada al concepto de víctima que la Ley 4/2015, de 27 de abril reguladora del Estatuto de la Víctima, art. 2, define como "toda persona física que haya sufrido un daño o perjuicio sobre su propia persona o patrimonio [...] o perjuicio económico directamente causados por la comisión de un delito".

El problema que suscita la traslación de este concepto al ámbito de los delitos socioeconómicos es fácilmente apreciable, si se tiene en cuenta que en la mayoría de ellos será difícil identificar a los concretos sujetos perjudicados ${ }^{31}$ por

únicamente una reparación parcial o disminución del daño referido al efectivo y exclusivamente cuantificable en términos económicos o financieros".

31 DE LA HERRÁN ("Aspectos técnicos de la atenuante (...)", ob.cit., p. 26) lo justifica en el siguiente sentido: "de lo contrario la atenuación penológica se llevaría a cabo en la contravención del Estatuto de la Víctima y de la doctrina del actus contrarius y de protección objetiva de la víctima que aplica la jurisprudencia del TS como criterio determinante en esta atenuante. No se ha de aplicar la atenuante de reparación o disminución del daño en aquellos delitos donde no confluyan víctimas en sentido estricto, pues no concurren intereses personales que deban ser tutelados o resarcidos. En cambio, la jurisprudencia, consciente de 
conductas como los daños a la libre competencia, el medio ambiente, etc.

Ante las restricciones del anterior concepto y las necesidades de la justicia restaurativa en el ámbito de los delitos socioeconómicos se ha planteado la posibilidad de manejar un concepto más amplio de víctima, en la línea de la Recomendación CM/Rec (2018) 8 del Consejo de Europa que se refiere a "otras personas directa o indirectamente afectadas por el delito”. Así, GUARDIOLA LAGO, identifica diferentes grupos de casos que pueden incluirse en los delitos económicos: víctima persona jurídica, víctima masa, víctimas de violencia corporativa y víctima difusa ${ }^{32}$. Por esta vía podría darse entrada a los sujetos que padecen las consecuencias de la afección a bienes jurídicos "colectivos" (como los derechos de los trabajadores, intereses económicos de los consumidores, etc.), "difusos" (como el medio ambiente, ordenación del territorio, etc.) e incluso los denominados "supraindividuales de titularidad estatal" (como los delitos contra la Hacienda Pública, cohecho o malversación, etc. $)^{33}$.

este hecho, declaró en STS de 22 de marzo de 2011 que lo que pretende la atenuante de reparación del daño es efectivamente incentivar el apoyo y la ayuda a las víctimas en general, pero que esto no excluye a la Hacienda Pública, reconociendo así implícitamente que la atenuante ha sido interpretada desde su configuración en el CP en el sentido de que las personas jurídicas públicas o privadas no pueden ser categorizadas como "víctimas" hasta ese momento". En consecuencia, "se ha logrado adulterar el que debía ser uno de los mayores logros de la política-criminal moderna. Así, estos sujetos han obtenido la posibilidad de lograr en sus eventuales sentencias condenatorias la aplicación de la atenuante prevista en el art. $21.5 \mathrm{CP}$, aun y cuando el caso concreto no responda a los supuestos donde debiera ser reconocida".

32 GUARDIOLA LAGO, M. ${ }^{\mathrm{a}}$ J., “¿Es posible la justicia restaurativa en la delincuencia de cuello blanco?", en Estudios Penales y Criminológicos, Vol. XL, 2020, pp. 571 y ss.

33 En todo caso, la posibilidad quedaría excluida en los delitos contra bienes jurídicos "estatales" (delitos contra la Constitución, orden público, etc.). En estos casos no debería ser posible puesto que su defensa se atribuiría en exclusiva al Estado, a través del Ministerio público y la Abogacía del Estado. Ahora bien, en estos casos no se excluye la posibilidad de 
Este entendimiento amplio del concepto de víctima podría dar cabida a los colectivos afectados, con el consiguiente efecto atenuante a la reparación del daño causado a los mismos. Si esa posibilidad ha sido o no aprovechada en la práctica jurisprudencial es algo sobre lo que se trata a continuación.

\section{Aplicación jurisprudencial}

Si la evolución de la configuración legal de la atenuante ha tendido a su extensión, la aplicación jurisprudencial no le ha ido a la zaga, abundando en la voluntad de procurar la máxima satisfacción de la víctima.

\subsection{El valor atenuante de la reparación a cargo de terceros}

La jurisprudencia viene considerando que, a pesar de la gran objetivación de la atenuante, la consignación de la indemnización debe realizarse de forma personal, como se deriva de la literalidad del art. $21.5^{\mathrm{a}} \mathrm{CP}$ que exige "haber procedido el culpable". A partir de esa constatación, los tribunales ${ }^{34}$, han negado efectos atenuantes a: a) los pagos realizados por compañías de seguros en cumplimiento del seguro obligatorio ${ }^{35}$; b) la satisfacción de las fianzas o reque-

que concurran otros niveles, colectivo, difuso o incluso, dependiendo de cómo se ejecute el delito o de las circunstancias del caso, también puedan resultar victimizaciones individuales. De todos modos, como se puede observar, este tipo de bienes jurídicos estatales quedan fuera del ámbito de la delincuencia económica, objeto de nuestro trabajo.

34 Vid., p. ej., la reciente Sentencia del Tribunal Supremo 272/2020, de 6 de febrero.

35 Así, entre otras, se pronunció la STS de 13 de mayo de 1997, STS de 20 de octubre de 2006 o STS de 27 de diciembre de 2011, al rechazar la atenuante por considerar que era necesario requerir un esfuerzo reparador mayor que la simple contratación de un seguro que, en algunas ocasiones, puede llegar a ser obligatorio. Sin embargo, en algunas sentencias, como recoge TAMARIT SUMALLA ("La difícil asunción (...)", ob.cit., p. 9) se ha considerado válido el pago realizado por el asegurador, pues "supone un evidente resarcimiento del daño" (SAP de Madrid de 11 de enero de 2001) "o de que tal consecuencia se derive 
rimientos exigidos por los juzgados ${ }^{36}$; c) la realización de las conductas impuestas por las distintas administraciones ${ }^{37}$; y d) la simple restitución de objetos hallados por parte de la administración de justicia.

Con todo, no han faltado excepciones a esa línea interpretativa: a) alguna sentencia ha reconocido el valor atenuante del pago de la fianza que no deja de ser una conducta del culpable, como exige la literalidad del art. 21.5 $\mathrm{CP}^{38}$; b) algunas sentencias de las audiencias provinciales han

de la propia naturaleza del contrato de seguro" (SAP de Zaragoza de 3 de febrero de 1999). De admitirse estas tesis, como dicho autor señala, "atentaría contra el carácter personal e intransferible de la pena".

36 Entre muchas otras, así se pronunció la STS de 13 de mayo de 2004 al considerar que "la consignación tuvo lugar una vez producido el requerimiento contenido en la parte dispositiva del auto de procesamiento (...) debiendo entenderse que fue este el motivo y no otro el de la consignación de cantidad aludida" concluyendo que en estos casos no podía aplicarse la atenuante. Más recientemente, la STS 438/2018, de 3 de octubre, del Caso de las tarjetas Black, en su Fundamento Jurídico 160 establece la diferencia de la atenuante objeto de este estudio y la satisfacción de la fianza al señalar que "la prestación de fianza no es admitida por la jurisprudencia de esta Sala como suficiente para la apreciación de la atenuante de reparación del daño (...) Simplemente se trata de una actuación dirigida, no a indemnizar, sino a garantizar una eventual responsabilidad civil, que solo se hará efectiva si recae condena penal (...) Es una situación distinta y no equiparable a la que se produce cuando el importe del daño, total o parcial, se le entrega directamente, o cuando la consignación se hace, no con la finalidad de garantizar aquella eventual responsabilidad civil, sino con la de hacer entrega inmediata al perjudicado".

37 Se ha planteado ampliamente esta cuestión respecto a la reparación de daños ambientales después del requerimiento realizado por la administración ambiental derivado de la implementación de la Directiva 2004/35/CE. Ampliamente sobre esta cuestión negando el efecto reparador en estos casos BAUCELLS LLADÓS, J., "La atenuante de reparación del daño ambiental tras la Ley de responsabilidad ambiental", en Pigrau Solé, A. (Coord.) Nuevas perspectivas de la responsabilidad por daños al medio ambiente, Madrid, Ministerio de Medio ambiente, 2006, especialmente pp. 116 y ss.

38 Aunque el TS no contempla las fianzas como pago adelantado de la responsabilidad civil, algunas sentencias han considerado que el pago de fianzas puede dar lugar a la aplicación de la atenuante. Vid STS de 15 
apreciado la atenuante de reparación ante pagos indemnizatorios realizados por compañías de seguros ${ }^{39}$; y c) se viene admitiendo sin problemas la llamada "reparación por delegación a tercero", aunque en estos casos -si existe una satisfacción económica- sólo es admisible siempre y cuando la misma se realice por cuenta y orden del sujeto activo, y ante la imposibilidad por su parte de llevar a cabo dicha conducta ${ }^{40}$, como puede suceder cuando se encuentra en prisión y ordena a un tercero que satisfaga la indemnización ${ }^{41}$.

En suma, cabe defender la aplicación de la atenuante cuando responde a la voluntad del culpable, aun cuando no sea éste quien aporte los medios, que pueden proceder de un familiar, un amigo o -para el tema que nos ocupa- la persona jurídica para la que trabaja o a la que representa el acusado, lo que puede derivar en una situación privilegiada de quien se limita simplemente a depositar la suma recibida como

de diciembre de 2004, STS de 16 de septiembre de 2002 o STS de 28 de febrero de 2003.

39 Por ejemplo, GARCIA SOLÉ/MARTÍ GARCIA-MILÀ ("Justicia restaurativa (...)", ob.cit., p. 119) llaman la atención sobre esta jurisprudencia minoritaria. Vid. SAP de Barcelona de 17 de noviembre de 2010, SAP de Madrid de 15 de febrero de 2010 y de 15 de enero de 2010.

40 Vid. STS de 30 de octubre de 1991, STS de 6 de junio de 1995, STS de 6 de noviembre de 1995 o STS de 4 de noviembre de 2010. En ellas se acepta dicha reparación delegada en persona distinta al propio agente, siempre "que haya sido el mismo sujeto agente quien ha decidido y encargado a terceros la actividad tendente a reparar o a facilitar la persecución del delito ante la imposibilidad de llevarla a cabo personalmente".

41 La doctrina también se ha manifestado ampliamente a favor de esta posibilidad. Vid. MAGRO SERVET, "Doctrina jurisprudencial (...)", ob.cit., p. 11; TAMARIT SUMALLA, "La difícil asunción (...)", ob.cit., p. 9; MUÑOZ CUESTA, J.C., y otros, "Reparación o disminución del daño causado", en Las circunstancias atenuantes en el Código Penal de 1995, Aranzadi, Pamplona, 1997, p. 142. SOLETO-GRANÉ (La reparación económica de la víctima (...), ob.cit., pp. 526-527) apunta que, si ello no fuera posible "supondría discriminatorio para aquellos acusados en prisión provisional frente a los que se encuentran en libertad". 
donación o préstamo por parte de la empresa o el lobby de turno ${ }^{42}$.

Del mismo modo, podrían considerarse injustamente privilegiados quienes se benefician de la actuación del coacusado que por su mayor poder económico se apresta a la satisfacción de la responsabilidad civil de la que responde solidaria o subsidiariamente con los demás. Como ha advertido DE LA HERRÁN a propósito de dos casos de delincuencia económica bastante conocidos en los que se han visto implicados célebres futbolistas, el Tribunal Supremo posibilita "que el efecto atenuador de la reparación realizada tan sólo por quien se benefició de las consecuencias del delito, se extienda a otros condenados que no han tenido un beneficio económico directo, pero que sí fueron copartícipes del delito"43.

2.2. El impacto de la renuncia de la víctima sobre las posibilidades de atenuación

Como recoge TAMARIT, la jurisprudencia "acepta de modo indistinto el pago directo al perjudicado o la consignación judicial del quantum de la responsabilidad civil", destacando, especialmente, la STS de 17 de octubre de 1998, porque acepta la consignación en un supuesto en que el perjudicado había renunciado a la indemnización ${ }^{44}$.

42 Crítico con esta contradicción jurisprudencial MANZANARES, J. L., Mediación, reparación y conciliación en el Derecho Penal, Comares, Granada, 2007, p. 67.

43 DE LA HERRÁN ("Aspectos técnicos de la atenuante (...)", ob.cit., p. 21) refiriéndose a la STS de 17 de marzo de 2004, en la que dos administradores de una sociedad limitada son condenados por un delito de malversación de caudales públicos y extiende el efecto atenuador de la reparación realizada por un acusado al otro acusado. $\mathrm{O}$, mucho más conocida, en el caso "Messi" el Tribunal expande el efecto atenuador de la reparación satisfecha por el juzgador a su padre, que mantiene la condición de cooperador en la comisión del delito (SAP de Barcelona de 5 de julio de 2016).

44 TAMARIT SUMALLA, "La difícil asunción (...)", ob.cit., p. 6. 
En este mismo sentido, más recientemente, la SAP de Madrid, núm. 209/2017, de 24 de mayo, que estimó la concurrencia de la atenuante de reparación al consignar, el acusado, 300 euros en "concepto de responsabilidad civil aun cuando no fue reclamada por la víctima"; dicha atenuación se justifica en la sentencia del siguiente modo "como se ha expresado por la jurisprudencia de esta Sala (Sentencia núm. 285/2003, de 28 de febrero, entre otras), lo que pretende esta circunstancia es incentivar el apoyo y la ayuda a las víctimas, lograr que el propio responsable del hecho delictivo contribuya a la reparación o curación del daño de toda índole que la acción delictiva ha ocasionado, desde la perspectiva de una política criminal orientada por la victimología, en la que la atención a la víctima adquiere un papel preponderante en la respuesta penal" 45 .

Con ello se impide que la aplicación de la atenuación quede supeditada a la voluntad de la víctima, evitando caer en la paradoja que supondría que los supuestos en que la víctima se considera satisfecha sin necesidad de reparación quedaran excluidos de la atenuación.

2.3. La excepcional admisibilidad de la reparación simbólica

Hasta la fecha, la concepción mayoritaria de la atenuante de reparación la ha supeditado a la satisfacción de una cantidad económica, equiparada prácticamente a la satisfacción de la responsabilidad civil. Sin embargo, la progresiva penetración de las ideas de la justicia restaurativa en nuestra Administración de Justicia se ha dejado ver en la ocasional aceptación de la "reparación simbólica" como pudiera ser la donación de sangre, la asunción de compromisos de obrar, etc. En este sentido se pronuncia la SAP de

45 Vid. DOMingo MONFORTE, J.- PEÑAlOSA TORNÉ, C., "La atenuante de reparación del daño. Tratamiento legal y jurisprudencial”, en Diario La Ley, núm. 9615, 2020, p. 2. 
Valencia 57/2019, de 6 de febrero, al destacar la admisión de esta atenuante por la jurisprudencia "no sólo en el caso de una reparación material, sino también en el caso de una reparación simbólica", aunque no se nos ocultan los problemas aplicativos de este criterio a los delitos socioeconómicos.

En la jurisprudencia, fundamentalmente, se ha admitido en los siguiente dos supuestos: a) por un lado, el de insolvencia del reo o b) por otro, aquellos en los que el daño no es evaluable económicamente o, incluso, siéndolo, las necesidades reparatorias van más allá de lo económico ${ }^{46}$.

Del mismo modo, en la doctrina también se oyen voces en favor de un concepto de reparación amplia que incluya la de carácter moral ${ }^{47}$. Sin embargo, como destaca TAMARIT, los gestos que podrían integrar la reparación moral, como la petición seria de disculpa a la víctima, no consiguen la aceptación de la práctica, ignorando "una aportación esencial de la investigación victimológica, que pone de manifiesto como las víctimas manifiestan en un gran número de ocasiones mayor interés o satisfacción por lograr una disculpa o algún tipo de reparación moral que por la indemnización monetaria"48. En la misma línea se pronuncia SOTO NIETO al señalar que la atenuante de reparación del daño cabe "cuando el culpable trata de reparar los efectos del delito por otras vías alternativas" como la petición de perdón o cualquier otro género de satisfacción (como la donación de sangre) que podrían tener un cauce por el camino de la analogía ${ }^{49}$.

46 Entre estas sentencias destacan STS de 5 de febrero de 2008 o STS de 20 de marzo de 2013.

47 Vid. MAGRO SERVET, "Doctrina jurisprudencial (...)", ob.cit., p. 6. En este sentido, SAP de Barcelona, núm. 925/2010, de 4 de noviembre.

48 TAMARIT SUMALLA, "La difícil asunción (...)", ob.cit., p. 6. Destaca, también, el papel decisivo de la reparación simbólica, GARRO CARRERA, Atenuantes de reparación (...), ob.cit., pp. 65-66.

49 SOTO NIETO, "Atenuante de reparación (...)", ob.cit., p. 1. Vid. STS de 4 de febrero de 2000. 


\subsection{La posibilidad de apreciación de oficio}

Como regla general, el Tribunal Supremo ha venido admitiendo el examen de oficio de aquellas circunstancias favorables al acusado, siempre que hayan sido objeto de prueba practicada en el plenario, con independencia de que hayan sido formalmente pretendidas por alguna de las partes $^{50}$. De acuerdo con ello, la jurisprudencia ha venido estimando de oficio la atenuante de reparación del daño, bajo la condición de que el reintegro de la cantidad que la fundamenta haya sido admitido por todas las partes, sin que, por tanto, se ocasione indefensión alguna a las partes acusadoras por el simple hecho de que no haya sido incluida formalmente en la calificación de los hechos ${ }^{51}$.

\section{denado}

2.5. La valoración de la capacidad económica del con-

Como ya ha sido dicho, el código penal reconoce efecto atenuador de la pena tanto a la reparación total como la parcial $^{52}$. Pese a ello, la jurisprudencia puntualiza que, para admitir la reparación parcial hay que tener en cuenta las circunstancias del caso, entre las que destaca la capacidad económica del acusado ${ }^{53}$. Ahora bien, si con ello se consigue evitar la discriminación por falta de capacidad económica ${ }^{54}$, nada puede hacerse frente a la mayor facilidad que tienen quienes disponen de mayores recursos.

Llegados a este punto, procede llamar la atención sobre el hecho de que uno de los problemas principales con los que tropieza la lucha contra la delincuencia económica es

50 Vid., entre otras, la STS núm. 1001/2016.

51 Vid., entre otras, SAP de Soria de 5 de noviembre de 2018.

52 Vid. supra epígrafe III. 1. 1.3.

53 DOMINGO MONFORTE-PEÑALOSA TORNÉ ("La atenuante de reparación del daño (...)", ob.cit., p. 2) sostienen que, la consideración a la capacidad económica del autor y su esfuerzo evita el peligro de discriminación.

54 Vid. MAGRO SERVET, "Doctrina jurisprudencial (...)", ob.cit., p. 6. 
precisamente la general facilidad del delincuente económico para ocultar sus bienes y aparentar una falsa insolvencia ante la impotencia de la Administración de justicia para investigarla $^{55}$. Por este motivo, deben extremarse las precauciones ante una indeseable aplicación de la atenuante a quienes no reparan completamente cuando disponen de medios para hacerlo.

\subsection{Condiciones de la especial atenuación.}

$\mathrm{El}$ art. $66 \mathrm{CP}$ no excluye a ninguna atenuante de las posibilidades de la especial cualificación que, cuando no concurre con ninguna agravante, puede dar lugar a la aplicación de la pena inferior en uno o dos grados, (ap. 1, 2a), mientras que, cuando concurre con alguna agravante, permite la aplicación de la pena inferior en grado si persiste un fundamento cualificado de atenuación (ap. 1, 7 ${ }^{\mathrm{a}}$ ).

En cuanto a la reparación del daño, la jurisprudencia la considera como muy cualificada "cuando el montante total a reparar asciende a una cantidad muy elevada, y el reo lo ha puesto a disposición de la víctima de forma integra o prácticamente íntegra - por lo que no se demanda, ni, aun así, la totalidad-y con bastante antelación a la celebración del juicio oral" ${ }^{56}$.

55 REBOLLO VARGAS /CASAS HERVILLA ("El proceso penal y la investigación de la delincuencia económica”, en García Arán, M. (Dir.), La delincuencia económica. Prevenir y sancionar, Tirant lo Blanch, Valencia, 2014, pp. 345-346) reconocen que "en estos casos, los Juzgados se limitan, las más de las veces, tras la mera afirmación de insolvencia efectuada por el reo, a realizar una consulta telemática ante la Agencia Estatal Tributaria a fin de constatar qué bienes inmuebles y qué vehículos obran a su nombre, cuáles han sido los ingresos declarados en el último ejercicio fiscal, así como cuántas entidades bancarias disponen de cuentas en las que aparezca como titular el reo".

56 Así literalmente en STS de 29 de enero de 2008. DOMINGO MONFORTE-PEÑALOSA TORNÉ ("La atenuante de reparación del daño (...)", ob.cit., p. 2) señalan como paradigmática la SAP de Madrid, núm. 469/2017, de 24 de julio, que aplicó la atenuante como muy cualificada "al valorar el esfuerzo del acusado que nada más 
Por lo tanto, como ya ha advertido la doctrina, los criterios aplicativos del TS permiten augurar que "los grandes delincuentes económicos tienen mayores vías de acceso a la aplicación de esta atenuante, dada su apreciación basada en la alta cantidad a reparar y su efectiva reintegración, lo que sin lugar a duda solo es posible para un gran delincuente económico solvente y de alto poder adquisitivo"57. Sin embargo, también es cierto que, como señala FERNÁNDEZ PANTOJA, para su aplicación como muy cualificada, el Tribunal Supremo exige requisitos añadidos a la reparación total del daño, pues lo contrario "supone una objetivización inadmisible y contraria al fin preventivo general de la pena"

La aplicación como muy cualificada en los supuestos de delincuencia económica se incrementa porque todas las circunstancias agravantes que podrían neutralizar su impacto

percibir la parte correspondiente a la herencia de su padre hizo frente al pago de la responsabilidad civil a la empresa perjudicada, aun cuando no cubría el total del importe reclamado".

57 DE LA HERRÁN ("Aspectos técnicos de la atenuante (...)", ob.cit., p. 27), trayendo a colación la STS de 24 de mayo de 2017 sobre el caso Messi, cuyo montante defraudado ascendía a los 4 millones de euros. Allí se considera como muy cualificada "por lo importantísimo» de las sumas abonadas"; o la Audiencia Provincial de Madrid, en su reciente Sentencia de 22 de enero de 2019, que condena de conformidad por cuatro delitos contra la Hacienda pública a Ronaldo, lo que finaliza con la sustitución de las penas privativas de libertad por la pena de multa. Con anterioridad DE VICENTE MARTÍNEZ, "Circunstancias (...)", ob.cit., p. 187.

58 FERNÁNDEZ PANTOJA ("La reparación del daño como respuesta al delito", en Estudios Jurídicos Penales y Criminológicos, en Homenaje al Prof. Dr. Dr. H. C. Mult. Lorenzo Morillas Cueva, Suárez López, Barquín Sanz, Benítez Ortuzar, Jiménez Díaz, Sainz-Cantero Caparrós (Dirs.), Dykinson, Madrid, 2018, p. 213; p. 220), asimismo, destaca que, para "una correcta aplicación de la atenuante, el Tribunal Supremo exige que esa reparación sea suficientemente significativa y relevante, pues no procede conceder efecto atenuatorio a acciones fácticas que únicamente pretenden buscar la minoración de la respuesta punitiva sin contribuir de modo eficiente y significativo a la efectiva reparación del daño ocasionado" (ATS 1487/2016, de 22 de septiembre). 
sobre la pena (alevosía, ensañamiento, disfraz, móviles discriminatorios, reincidencia, ...) están diseñadas para la delincuencia marginal y no para este perfil de delincuente ${ }^{59}$.

Si trasladamos las anteriores consideraciones a los delitos económicos las posibilidades de que, ante la completa reparación del daño se consiga la rebaja en uno o dos grados se refuerzan por el hecho de que difícilmente va a tener que compensarse con circunstancias agravantes que en su concepción originaría no tenían a los delitos económicos en su punto de mira.

Por todo ello, es necesario repensar la interpretación y aplicación de esta atenuante en el ámbito de los delitos socioeconómicos. El hecho de que la jurisprudencia haya considerado la reparación en términos objetivos, estrictamente económicos, asimilados a la satisfacción de la responsabilidad civil, implica un privilegio para el delincuente económico, con su consecuente afectación a la eficacia preventiva del derecho penal.

\section{La reparación del daño como vía de tutela de la víctima y eventual fuente de discriminación}

Tras la exposición de la configuración legal, y aplicación jurisprudencial de la atenuante, a continuación, dedicaré mi atención a identificar las líneas político-criminales que se hallan tras la regulación legal y orientan su aplicación jurisprudencial, avanzando desde ya la necesaria revisión de las mismas a la luz de los principios de la justicia restaurativa.

\section{La ideología victimológica tras la atenuante}

En las páginas anteriores hemos visto cómo la evolución de esta atenuante la ha conducido hasta su estado

59 Vid. REBOLLO VARGAS / CASAS HERVILLA, "El proceso penal (...)", ob.cit., p. 344 . 
actual, caracterizado por su eminente objetividad y generosidad aplicativa. Ello no es casual sino más bien coherente con un determinado fundamento de la atenuante de reparación que entronca con las modernas corrientes victimológicas. Como ya hemos tenido ocasión de apuntar, es evidente que reparar el daño con carácter posterior a la consumación del delito, impide encontrar el fundamento de esta atenuante en una disminución del injusto o de la culpabilidad del sujeto ${ }^{60}$.

Por el contrario, la mayoría de la doctrina ${ }^{61}$, así como la jurisprudencia consolidada ${ }^{62}$ consideran que, en su actual configuración, la atenuante analizada conecta con la preocupación de la política criminal contemporánea por incentivar el apoyo y la ayuda a las víctimas, en especial, desde el auge de la victimología a partir de los años 90 .

Como ha sintetizado el Tribunal Supremo "lo que pretende esta circunstancia es incentivar el apoyo y la ayuda a las víctimas, lograr que el propio responsable del hecho delictivo contribuya a la reparación o curación del daño de toda índole que la acción delictiva ha ocasionado, desde la perspectiva de una política criminal orientada por la victimología, en la que la atención a la víctima adquiere un papel preponderante en la respuesta penal"63. $\mathrm{O}$, en otras palabras, la atenuante "no hace derivar la disminución de la responsabilidad de una inexistente disminución de la culpabilidad por el hecho, sino de la legítima y razonable pretensión del Legislador de dar protección a la

60 Vid. supra epígrafe II.

61 Vid. TAMARIT SUMALLA, "La difícil asunción (...)”, ob.cit., p. 17; DE LA HERRÁN, "Aspectos técnicos de la atenuante (...)", ob.cit., pp. 24 y ss.; GARCIA SOLÉ/MARTÍ GARCIA-MILÀ, "Justicia restaurativa (...)", ob.cit., pp. 111 y ss.; MAGRO SERVET, "Doctrina jurisprudencial (...)", ob.cit., pp. 1 y ss., entre otros.

62 Vid. STS 16 de enero de 2007, STS 25/2018, de 15 de marzo, STS 272/2020, de 6 de febrero, entre otras.

63 Vid. STS de 2 de diciembre de 2003 o STS de 28 de febrero de 2003, como ejemplo de las muchas citadas en BAUCELLS LLADÓS, "La atenuante de reparación del daño (...)", ob.cit., p. 212, nota 10. Asimismo, vid. nota 63 . 
víctima y favorecer para ello la reparación privada posterior a la realización de delito" ${ }^{64}$.

\section{El peligro del injustificado privilegio del delincuen- te socioeconómico}

Como hemos ido apuntando en las páginas anteriores los criterios aplicativos de la atenuante de reparación del daño han favorecido al delincuente socioeconómico.

En primer lugar, la configuración objetiva de la atenuante -al margen de cualquier tendencia subjetiva- permite al delincuente socioeconómico, con mayores niveles de solvencia, recurrir fácilmente a la reparación con el fin de atenuar la pena, aun cuando ello se debe a la única finalidad estratégica de conseguir un beneficio penológico recomendado por su abogado.

En segundo lugar, el mayor poder del que suelen gozar los delincuentes económicos puede utilizarse no solo para la comisión del delito, sino también para la ocultación de éste y los beneficios que le reporta, obstaculizando la satisfacción de las responsabilidades pecuniarias, sin que ello impida por completo gozar de la atenuación por reparación parcial del daño.

En tercer lugar, la mayor capacidad económica de la que suelen gozar estos delincuentes les facilita la completa reparación del daño que les abre la puerta a la aplicación de la atenuación muy cualificada.

En cuarto lugar, en la delincuencia económica no es rara la actuación en cooperación con otros o en nombre de personas jurídicas, que pueden satisfacer las responsabilidades civiles, permitiendo la aplicación de la atenuante a quien no ha hecho ningún esfuerzo reparador.

Si a todo ello le unimos los efectos expansivos de los criterios jurisprudenciales, los beneficios para el delincuente económico se multiplican. Me refiero, por ejemplo, a la

64 STS núm. 1517/2003, 18 de noviembre. 
aplicación de la atenuante analógica allí donde no llega la estricta atenuante de reparación del daño, cuando se repara justo antes de la sentencia, después de haber especulado y visto lo mal que había ido el juicio oral; la admisibilidad de la reparación simbólica para el insolvente, no siempre real; la admisión de la aplicación de oficio; e incluso en supuestos donde no hay víctima alguna que reclame la responsabilidad civil.

A los inconvenientes de una interpretación, en ocasiones, demasiado generosa se suman los peligros que derivan de la ausencia de control judicial alguno acerca de la procedencia de los fondos. Un rápido examen de algunos de los casos más mediáticos desvela que en ninguno de ellos se ha exigido probar la procedencia lícita del dinero, (así, en el caso Noos $^{65}$, caso Fórum Filatélico ${ }^{66}$, caso Gürte ${ }^{67}$ ). Como destaca DE LA HERRÁN, a propósito de este último, la atenuante se aplica por la colaboración de los acusados "en la agilización temporal de la repatriación de los activos depositados en el paraíso fiscal; activos que, de otro modo, reconoce la sentencia, se hubieran logrado repatriar igualmente" ${ }^{88}$.

En definitiva, el modo como se ha venido interpretando y aplicando la atenuante de reparación del daño por parte de la jurisprudencia consiente la aplicación de penas privativas de libertad de muy corta duración ${ }^{69}$ que acaban suspendidas o sustituidas, con gran impacto en la eficacia preventiva del derecho penal en materia socioeconómica.

65 Vid. STS 277/2018, de 8 de junio.

66 Vid. SAN 2738/2018, de 13 de julio.

67 Vid. Sentencia del Juzgado Central de lo Penal de 11 de junio de 2018.

68 DE LA HERRÁN, "Aspectos técnicos de la atenuante (...)", ob.cit., pp. 28 y 29.

69 Este efecto viene reforzado por el hecho que, pese a la gravedad de muchas de estas conductas, el legislador penal prevé penas de cárcel desproporcionadamente cortas o no privativas de libertad. Crítico sobre esta cuestión vid. BAUCELLS LLADÓS, J., "Sistema de penas para el delincuente económico", en Cuadernos de política criminal, núm. 107, 2012, pp. 163 y ss. 


\section{Las atenuaciones específicas de algunos delitos eco- nómicos}

A la corriente de apoyo a las víctimas, se suma una corriente político criminal conocida con el nombre de "derecho penal del amigo" ${ }^{70}$ que ofrece un trato de privilegio al delincuente económico, en consideración a elementos que van más allá del hecho delictivo, como el carácter empresarial de los autores ${ }^{71}$, o los intereses económicos y laborales que gestionan y favorecen la mercantilización o la privatización del conflicto. Entre muchas de sus facetas premiales ${ }^{72}$, me centro únicamente en el mayor efecto atenuante que se ha ofrecido a la reparación en este tipo de delitos.

\subsection{La atenuante cualificada de reparación del daño ambiental}

La primera muestra del llamado "derecho penal del amigo" la hallamos en la regulación de los delitos relativos a la ordenación del territorio, el patrimonio artístico o la

70 El nombre "derecho penal del amigo" empieza a consolidarse con éxito por su doble connotación. En primer lugar, por oposición al "derecho penal del enemigo" que no privilegia sino se presenta como un derecho penal de excepción para luchar contra el disidente político (fundamentalmente terrorismo) y por su referencia a la relación de amistad entre el político legislador y el delincuente empresario. Vid. VIDALES RODRÍGUEZ, C., "Derecho penal del amigo (Reflexiones críticas acerca de la reciente modificación de los delitos contra la Hacienda Pública y la Seguridad Social)", en Revista de derecho y proceso penal, núm. 32, 2013.

71 Califica de derecho penal de autor QUINTERO OLIVARES, G., "El castigo de la delincuencia económica y el riesgo de derecho penal de autor", en Liber Amicorum, Estudios Jurídicos en Homenaje al Prof. Dr. Dr. h. c. Juan M. ${ }^{a}$. Terradillos Basoco, Tirant lo Blanch, Valencia, 2018, pp. 407 a 425.

72 Fundamentalmente este trato privilegiado al delincuente económico y al corrupto se manifiesta en la previsión de penas cortas de privación de libertad que permiten su suspensión; una alta tasa de concesión de indultos; la previsión de excusas absolutorias y circunstancias muy atenuantes; progresión en grado penitenciario; cuando no incluso amnistías fiscales. 
protección del medio ambiente, cuyo artículo $340 \mathrm{CP}$, prevé que "si el culpable (...) hubiera procedido voluntariamente a reparar el daño causado, los Jueces y Tribunales le impondrán la pena inferior en grado a las respectivamente previstas". El carácter especialmente privilegiado de este tipo de reparación es más que evidente. En primer lugar, por los extraordinarios efectos atenuantes, que desbordan el límite mínimo del marco penal abstracto de la pena hasta alcanzar la inferior en grado que puede llevar a la remisión condicional de la pena en la casi totalidad de los casos. Pero, el efecto aumenta, si valoramos que -al quedar al margen del régimen de determinación de la pena previsto en el artículo $66 \mathrm{CP}$ - no podrá compensarse con otras agravantes genéricas, con lo que la rebaja de pena queda asegurada. A mayor abundamiento, la circunstancia específica no exige, a diferencia de la genérica, que la reparación se produzca con anterioridad al juicio oral, lo que permite que se aplique también a la vista del desarrollo del juicio oral, parece, entonces, que el único límite temporal será el momento en que se dicte sentencia ${ }^{73}$.

Como recoge PUENTE ABA, si la reparación se efectúa antes del inicio del juicio oral existirá una concurrencia entre el art. 21.5 $\mathrm{CP}$ y el art. $340 \mathrm{CP}$. Ahora bien, parece que es más beneficiosa la atenuación prevista en el art. 340, que conduce directamente a la rebaja de la pena en un grado, a diferencia de la atenuante genérica, que podría limitarse a la imposición de la mitad inferior de la pena prevista para el delito. Dicha autora destaca que, a primera vista, "parece que el legislador ha querido dotar de una especial relevancia a la reparación en el ámbito del medio ambiente"; sin embargo, de apreciarse la atenuante genérica como muy cualificada permitiría imponer la pena inferior en uno o dos grados, siendo entonces mayor la atenuación que la prevista

73 Vid. PUENTE ABA, M. ${ }^{\text {a }}$, "La reparación en el marco del derecho Medioambiental", en Anuario da Facultade de Dereito da Universidade da Coruña, núm. 8, 2004, p. 633; SILVA SÁNCHEZ, J.M., Delitos contra el medio ambiente, Tirant lo Blanch, Valencia, 1999, p. 178. 
en el art. $340 \mathrm{CP}^{74}$. Por este motivo, continúa PUENTE ABA, algunos autores sostienen que cuando la reparación es "muy cualificada", puede aplicarse la atenuante genérica con una rebaja de pena de hasta dos grados ${ }^{75}$.

Esta diferencia de trato puede observarse también en el modo en que la jurisprudencia menor ha ido aplicándola. Así, en un caso del cese de los vertidos, en consideración a que por sí solos permiten la regeneración del torrente, así como de la riera y de las aguas del Rio Besós, se aplicó el art. $340 \mathrm{CP}^{76}$. En cambio, se ha admitido la atenuante del art. $21.5^{\text {a }} \mathrm{CP}$ como muy cualificada, reduciendo la pena en dos grados, en un supuesto en que unos sujetos se limitaron a cesar la actividad contaminante, clausurando los vertederos ilegales, eliminándose el peligro para el medio ambiente ${ }^{77}$.

Como bien apunta PUENTE ABA, sí, ya de por sí, resulta complicado distinguir cuando la atenuante de reparación del daño ha de calificarse como simple o muy cualificada, "mayor complejidad aporta la mención específica de la reparación como una circunstancia que permite rebajar la pena en un grado en el delito ecológico"78.

74 PUENTE ABA, ult.ob.cit., p. 633. Vid. asimismo, PRATS CANUT, M.-MARQUÉS I BANQUÉ, M., Comentarios al Nuevo Código Penal, Quintero Olivares, G. (Dir.), Aranzadi, Pamplona, 2004, p. 1776.

75 PUENTE ABA, ult.ob.cit., pp. 633-634; SILVA SÁNCHEZ, Delitos contra el medio ambiente, ob.cit., p. 181.

76 Vid. SAP de Barcelona, de 23 de enero de 2002. BAUCELLS LLADÓS, "La atenuante de reparación del daño (...)", ob.cit., p. 213; PUENTE ABA, "La reparación en el marco (...)", ob.cit., p. 635.

77 Vid. SAP de Barcelona, de 12 de enero de 2001. BAUCELLS LLADÓS, "La atenuante de reparación del daño (...)", ob.cit., p. 213.

78 PUENTE ABA, ult.ob.cit., pp. 633-635. Un análisis detallado de los elementos comunes y las diferencias que separan la circunstancia genérica de la específica realiza VIDALES RODRÍGUEZ, C., "La reparación del daño en los delitos relativos a la ordenación del territorio y la protección del patrimonio histórico y del medio ambiente. Análisis del artículo 340 del Código Penal", en Estudios de Derecho Ambiental. Libro Homenaje al profesor Josep Miquel Prats Canut, Quintero Olivares, G.-Morales Prats, F. (Coord.), Tirant lo Blanch, Valencia, 2008, pp. 761 y ss. 


\subsection{La atenuante de regularización tributaria extem-}

poránea en el delito fiscal

La lista de atenuantes específicas continúa con la prevista para el delito fiscal, que, desde la reforma de $2012^{79}$, complementa el régimen de la excusa absolutoria (aps. 1 y 4 del mismo art. $305 \mathrm{CP})^{80}$, permitiendo la atenuación de la pena cuando se exceda el límite temporal máximo de la excusa.

El artículo 305.6 CP, establece que "los Jueces y Tribunales podrán imponer al obligado tributario o al autor del delito la pena inferior en uno o dos grados, siempre que, antes de que transcurran dos meses desde la citación judicial como imputado satisfaga la deuda tributaria y reconozca judicialmente los hechos"81. De nuevo, la satisfacción de la deuda tributaria, incluso después de conocer su imputación penal, permite rebajar la pena por debajo del marco penal

79 Sobre la situación previa a la reforma de 2012, CUGAT MAURI, M./BAÑERES SANTOS, F., "Delitos contra la Hacienda pública y la Seguridad social", en Álvarez García (Dir.), Derecho penal español. Parte especial II, Tirant lo Blanch, Valencia, 2011, pp. 793 ss.; IGLESIAS CAPELLAS, J., "La regularización de la defraudación tributaria constitutiva de delito contra la Hacienda Pública", en $R C y T$, CEF, núms. 341-342, 2011; sobre los cambios introducidos por la misma, y en concreto, sobre la nueva atenuante, críticamente, BOIX REIG, J., "Reflexiones sobre la reforma del Código Penal en materia de lucha contra el fraude tributario", en Diario La Ley, núm. 7966, 2012.

80 Sobre el concepto y condiciones de aplicación de la regularización tributaria, véase la Circular FGE 2/2009 sobre la interpretación del término regularizar en las excusas absolutorias previstas en los apartados 4 del art. 305 y 3 del art. 307 del Código Penal.

81 Como señalan CHOZA CORDERO y RIZO LEON ("Reparación del daño en los delitos contra la Hacienda Pública: Atenuante simple o atenuante muy cualificada", en Revista Aranzadi Doctrinal, núm. 4, 2020 , pp. 70 y ss.) la jurisprudencia, entre otras, SAP de Barcelona, núm. 140/2019, de 18 de enero o la SAP de Valencia, núm. 195/2017, de 21 de marzo, aplican este tipo atenuado si concurren todos sus requisitos, esto es: pago total de la deuda tributaria, dentro de los dos meses siguientes desde la citación como imputado, y reconocimiento de los hechos. 
abstracto, asegurando que prácticamente no haya ningún sujeto cumpliendo condenas en las cárceles españolas por delito fiscal. Según los datos del Consejo General del Poder Judicial e Instituto Nacional de Estadística sobre el año 2017, de los 1002 sujetos condenados por delitos contra la Hacienda pública y la Seguridad social, solo 254 habían sido privados de libertad. Y la tendencia va al alza, puesto que, en 2013, el porcentaje de privados de libertad era más alto: 203 respecto a 647 condenas $^{82}$.

Una vez superado el plazo de dos meses desde la citación judicial como imputado, de acuerdo con algún autor como CHOZA CORDERO y RIZO LEON, y al hilo de lo señalado en la SAP de Vizcaya, núm. 86/2018, de 17 de diciembre, podrá aplicarse la circunstancia atenuante genérica de reparación del daño del art. $21.5^{\mathrm{a}} \mathrm{CP}^{83}$. De acuerdo con la referida sentencia "(...) el hecho de que el art. 305.6 CP establezca una regla especifica de determinación de la pena para aquellos supuestos en que el obligado satisfaga la deuda tributaria y reconozca judicialmente los hechos antes de que transcurran dos meses desde la citación judicial como imputado, no supone que debamos interpretar que la atenuante genérica de confesión que aquí se nos pide, no sea aplicable. Considera esta Sala que esta interpretación restrictiva de la norma penal, que nada dice sobre la no aplicación al delito fiscal de las atenuantes genéricas, no es razonable ni se ajusta a derecho (...) En definitiva, considera la Sala que son de aplicación las dos atenuantes solicitadas por la defensa, la de confesión y la de reparación del daño".

Ahora bien, no se trata de una opinión indiscutida. En este sentido, CARDENAL MONTRAVETA, a partir del análisis de la SAP de Madrid, núm. 53/2019, de 22 de enero,

82 Así lo ha observado DE LA HERRÁN, "Aspectos técnicos de la atenuante (...)", ob.cit., p. 15.

83 CHOZA CORDERO-RIZO LEON, "Reparación del daño (...)", ob.cit., p. 71. 
que condenó al futbolista Cristiano Ronaldo como autor de cuatro delitos contra la Hacienda Pública, se pregunta que "qué sentido tiene lo dispuesto en el art. 305.6 CP si esta regulación no se concibe como una ley especial, que desplaza la atenuante genérica del art. $21.5 \mathrm{CP}$ y excluye su aplicación". Reflexión a partir de la que critica la sentencia que justifica la disminución de la pena en base a lo dispuesto en los arts. $21.5^{\mathrm{a}}$ y $66.1 \mathrm{CP}^{84}$.

Para concluir este epígrafe, es interesante señalar que el hecho de que en este tipo de delitos socioeconómicos no existan víctimas identificables o, mejor, tratándose de bienes colectivos, las víctimas seamos todos, ha permitido que el Estado priorice la reparación económica en una clara lógica de privatización del conflicto. A propósito de la atenuante ambiental, BAUCELLS ha considerado que se sitúa en lo que podríamos llamar "la privatización del conflicto" pues, "las propias Directivas europeas establecen que de lo que se trata es de "inducir a los operadores a adoptar medidas y desarrollar prácticas dirigidas a minimizar los riesgos de que se produzcan daños ambientales" aunque sea a costa de renunciar a la pena" ${ }^{85}$. Por otro lado, en relación con el pago de la deuda fiscal QUINTERO ha dicho irónicamente que "seguramente el razonamiento no confesado (porque además de otras cosas sería falso e inadmisible en un Estado de derecho) es que el delito fiscal se pacta con el Estado titular del ius puniendi, que por lo tanto puede decidir no ejercerlo" $"$.

84 CARDENAL MONTRAVETA, S., "La respuesta del derecho penal a los delitos fiscales de Cristiano Ronaldo (y de otros)", en La Ley Penal, núm. 136, 2019, p. 4.

85 BAUCELLS LLADÓS, "La atenuante de reparación del daño (...)", ob.cit., pp. 212-213.

86 QUINTERO OLIVARES, G., "La responsabilidad civil y la reparación en la política criminal contemporánea", en Responsabilidad civil ex delicto. Cuadernos de Derecho Judicial, Madrid, 2005, p. 23. 


\section{A modo de conclusión: una propuesta de aplicación de la atenuante de reparación del daño desde la justicia restaurativa}

Los inconvenientes que se derivan de los actuales criterios de aplicación de la atenuante a los delitos socioeconómicos aconsejan la aprobación y desarrollo de una ley específica sobre justicia restaurativa que se demuestre capaz de orientarla a la satisfacción de los fines que le son propios ${ }^{87}$. Con todo, el problema no se limita a la configuración legal de la atenuante, sino que se extiende a su aplicación jurisprudencial, puesto que han sido nuestros tribunales principales responsables de la impunidad de los grandes delincuentes económicos ${ }^{88}$.

Por tanto, más allá de las reformas legislativas que sean necesarias para desarrollar el modelo de justicia restaurativa y deconstruir el "derecho penal del amigo", de lege lata, es posible comenzar a revertir esta situación haciendo una interpretación y aplicación de las atenuantes de reparación desde esta perspectiva ${ }^{89}$.

Desde estas bases, podrían empezar a alcanzarse los fines propios de la justicia restaurativa antes incluso de alterar el tenor literal del art. $21.5^{\mathrm{a}} \mathrm{CP}$, a partir de la interpretación sistemática de este con el Estatuto de la víctima y los textos internacionales, así como la interpretación teleológica,

87 Vid. TAMARIT SUMALLA, "La difícil asunción (...)", ob.cit., p. 2. De todos modos, como hemos ido viendo a lo largo de esta obra, la aprobación del Estatuto de la víctima ya ha abierto algunos espacios de interpretación de las normas penales en perspectiva restaurativa.

88 En este sentido también DE LA HERRÁN, "Aspectos técnicos de la atenuante (...)", ob.cit., p. 27.

89 Pese a no ser la tendencia mayoritaria, alguna sentencia ha vinculado directamente esta atenuante con la justicia restaurativa. Así, la STS de 22 de octubre de 2013 (FJ.3) admite como fundamento de la atenuante "el empoderamiento que la víctima ha alcanzado en el proceso penal y el primordial deber de atender eficazmente a la reparación de los daños causados como exponente capital de la Justicia Restaurativa". 
que pone el foco en los efectos preventivos generales y especiales que serían deseables en un auténtico proceso restaurativo. Desde este punto de vista, entiendo que no son descartables los efectos de prevención general positiva que pueden derivarse de la colocación de las necesidades de la víctima en el centro de la justicia penal que al promover su satisfacción contribuirá a restablecer el ordenamiento jurídico y la confianza en la vigencia de la norma. Del mismo modo, la revisión de la atenuante a la luz de la justicia restaurativa podría contribuir a la realización de los fines de prevención general negativa, en la medida en que la reparación del daño supone una carga para quien lo costea que querrá evitar en el futuro. Por último, también puede servir a los fines de prevención especial positiva, en la medida en que la reparación puede contribuir a la reinserción ${ }^{90}$.

Para ello, considero que los tribunales deberían introducir los siguientes cambios en los criterios interpretativos de la atenuante.

1. En primer lugar para que el proceso reparador pueda alcanzar los referidos fines de tutela de bienes jurídicos y prevención del delito - en concreto preventivo general y especial positivo-, la atenuante de reparación debería contar, siempre que fuera posible, con la participación de la víctima en un auténtico proceso restaurativo. No es deseable que la atenuante se aplique-como viene haciéndose-por los jueces, automáticamente, fuera de un proceso restaurador y sin contar con la opinión y las necesidades de las víctimas, pues podría surgir el riesgo de la "compra" de la rebaja punitiva, que ni está al alcance de todos, ni ofrece una imagen edificante sobre el funcionamiento de la justicia, ni garantiza la completa satisfacción de las expectativas de la víctima.

90 En la doctrina, por todos, ROXIN, "Pena y reparación", ob.cit., p. 6. En este mismo sentido se han pronunciado algunas sentencias de forma aislada como STS núm. 145/2005, de 7 de febrero; STS núm. 1643/2003 de 2 de diciembre. 
El ofendido por el delito, como también el perjudicado, tienen la posibilidad de ejercer la acción penal y civil, que les da entrada en el proceso y les permite formular la petición restauradora. Ahora bien, por lo general, no se personan en la causa, dejando la defensa de sus intereses en manos del Ministerio Fiscal. En estas coordenadas la única institución que garantiza la participación directa de la víctima en el diálogo restaurativo es la mediación. Ahora bien, es una institución relativamente desconocida en la justicia penal de adultos, que convendría promover a fin de dar entrada a la víctima que no se hubiera constituido en parte, a fin de conocer su percepción del daño causado y los modos -no siempre económicos- de repararlo.

Por lo que respecta a las dificultades de identificación de las víctimas en la delincuencia económica, el propio Tribunal Supremo ha admitido, por ejemplo, que la Hacienda Pública pueda encontrar encaje en el concepto de "víctima" ". Por tanto, sería posible que un representante de la Administración tributaria participara en el proceso restaurativo que culminara con la aplicación de una atenuante de reparación.

Es más, la expresión "víctima" utilizada en el artículo $21.5^{\mathrm{a}}$ como persona sobre quien recae la acción delictiva, que no tiene por qué identificarse con el sujeto pasivo del delito, como titular del bien jurídico protegido, permite desde el tenor literal y una interpretación sistemática -que considere los textos internacionales y el Estatuto de la víctima- reconocer como víctimas a otros sujetos. Este anterior criterio puede tener especial utilidad en los delitos económicos que afectan a bienes jurídicos "colectivos" (derechos de los trabajadores,

91 Vid. STS de 28 de marzo de 2011, afirmando que el sujeto pasivo, como titular del bien jurídico protegido, es la propia Hacienda Pública, pero DE LA HERRÁN ("Aspectos técnicos de la atenuante (...)", ob.cit., p. 26), se cuestiona si ésta puede ser considerada "víctima" y si en efecto existe una víctima cuyo daño deba ser objeto de reparación. 
intereses económicos de los consumidores, etc.) en nombre de cuyo titular pueden ser llamados a participar representantes sindicales de la empresa donde se ha cometido el delito $\mathrm{u}$ organizaciones de consumidores del territorio en el que se ha delinquido. Asimismo, puede demostrar especial capacidad de rendimiento en las causas por delitos contra bienes jurídicos "difusos" (medio ambiente, ordenación del territorio, etc.) en cuya representación y defensa pueden intervenir organizaciones medioambientales. Incluso podría servir en causas por delitos contra la Hacienda o la Administración pública que afectan a los llamados bienes "supraindividuales de titularidad estatal" siempre y cuando se pueda identificar a perjudicados concretos. Sólo quedan excluidos de esta posibilidad los delitos que afectan a bienes jurídicos estatales en los que no es posible identificar a ninguna víctima ${ }^{92}$. En realidad, en relación con los bienes jurídicos estatales, el Tribunal Supremo ya ha empezado a pronunciarse tímidamente en esta línea. En este sentido, recientemente ha afirmado que no cabe la aplicación de la atenuante de reparación del daño en el delito de desórdenes públicos, dado que el sujeto perjudicado es la sociedad en su conjunto, de tal forma que la consignación de una cantidad de dinero sólo podrá considerarse reparación respecto a perjudicados concretos y determinados.

En los anteriores supuestos se relativiza la idea de la privatización del conflicto penal por la consustancial naturaleza pública del interés ofendido por los delitos socioeconómicos. Desde este punto de vista, la libertad negociadora de la víctima, que en el caso de los delitos patrimoniales tiene capacidad para exigir o perdonar la reparación del daño, en los delitos socioeconómicos, puede quedar mermada por las obligaciones de derecho público de exigir la reparación del daño provocado, por ejemplo, al Patrimonio o Hacienda pública. En otras palabras, la reparación del daño contri-

92 Vid. supra epígrafe III 1. 1.4. 
buye a devolver la resolución del conflicto a las partes, pero no actúa ni podría actuar del mismo modo en el caso de los delitos individuales o contra los bienes colectivos, pues en estos el daño causado tiene una dimensión social de la que no puede disponer la víctima más visible, como puede suceder en el caso de la publicidad engañosa, que, aunque golpee especialmente a un concreto consumidor, lesiona el conjunto del mercado.

2. Desde el punto de vista de la prevención general positiva, la reparación debería estar a la altura del daño realmente provocado.

La previsión legal de reparación pasa necesariamente por la posibilidad de cuantificar el daño. El problema es que ello no siempre es posible en los supuestos de delincuencia económica que afectan a bienes jurídicos colectivos o difusos en los que el daño es incuantificable o irreparable, En estos casos, parece razonable que el efecto de la atenuante sea también parcial, descartando no solo la rebaja en grado de la pena sino incluso la aplicación de su límite mínimo. De este modo podría evitarse que la atenuante de reparación interfiriera en los fines de prevención general negativa, que podrían quedar afectados por la idea de que el precio a pagar por el delito es inferior a lo conseguido con él.

3. Por otro lado, la atenuante podría ser también útil a los fines de prevención general positiva. Hasta el momento la jurisprudencia ha hecho una interpretación excesivamente generosa de la misma. Y no me refiero a que beneficie al reo, lo que es consustancial a su naturaleza, sino a que, en ocasiones, sobrepasa el tenor literal de la ley e incluso puede entrar en contradicción con su fundamento. Recuérdese, por ejemplo, que la atenuante de reparación del daño ambiental (art. $340 \mathrm{CP}$ ) se ha aplicado a supuestos en los cuales el sujeto se había limitado a cesar en la actividad contaminante sin restauración de la situación previa al delito. 
4. Por este motivo, desde una perspectiva restaurativa no sólo debería considerarse la participación y satisfacción de la víctima. En una lógica de prevención especial, debería considerarse también el esfuerzo y la capacidad reparadora del autor, alejando a la atenuante de cualquier identificación con la responsabilidad civil ex delito.

Con ello no me refiero a la valoración del arrepentimiento o el reconocimiento de responsabilidad -que pueden adquirir relevancia en otros momentos como la ejecución penal-, sino a la contribución positiva a la reparación de la víctima, en consideración a las capacidades del reo, alejándonos de la idea de la graduación de la atenuación en consideración a una "tabla de precios".

Desde este punto de vista considero que debería ponerse algún freno a la inclinación de la jurisprudencia menor a otorgar efecto atenuante al depósito de la fianza o el pago de la responsabilidad civil por parte de compañías de seguros, que puede deberse a una mera estrategia de defensa sin valor desde el punto de vista de la justicia restaurativa.

En segundo lugar, desde esa misma perspectiva, debería asegurarse que los efectos atenuantes no beneficien a sujetos distintos de quienes por su contribución personal a la reparación del daño garanticen la realización de fines preventivo especiales o generales. Para empezar, en ningún momento el código penal establece que la reparación pueda ser satisfecha por sujeto distinto al culpable. Desde este punto de vista, el tenor literal del articulo $21.5^{\mathrm{a}} \mathrm{CP}$ abona la tesis de que, en la reparación penal, a diferencia de la responsabilidad civil derivada del delito, debe ser el propio culpable quien satisfaga directamente las obligaciones derivadas de la reparación, y no un tercero ${ }^{93}$. Con ello no se pretende

93 Vid. FARALDO CABANA, P., "La aplicación analógica de las atenuantes de comportamiento postdelictivo positivo (los núms. $4^{\circ}$ y $5^{\circ}$ en relación con el núm. $6^{\circ}$ del artículo 21 del Código penal de 1995)", Facultade 
retroceder a otras épocas en las que lo que se valoraba era el arrepentimiento espontáneo o sentimiento de íntima contrición, sino interpretar la atenuante en armonía con los fines preventivos de la pena, y en especial el fin preventivo especial positivo, que pasan por la personal implicación del reo en el reconocimiento y restauración del daño provocado por el delito.

En tercer lugar, la perspectiva restaurativa nos lleva a exigir que, para poder beneficiarse de la atenuante, su beneficiario pruebe el origen lícito del dinero con el que quiera hacer frente a la reparación. Sólo mediante una reparación hecha a través de dinero lícito, que suponga a su vez el despojo veraz de una posición económica derivada de su actividad delictiva, se produce una real "reparación o disminución del daño" 94 .

5. Por último, la reparación en los delitos económicos se enfrenta a dos obstáculos más: el excepcional reconocimiento de la reparación simbólica, y las dificultades de identificar una víctima apta para participar en el proceso restaurativo.

Con todo, en los delitos contra bienes jurídicos "colectivos", "difusos" y "supraindividuales de titularidad estatal" los representantes de colectivos afectados pueden participar en procesos restaurativos. Un diálogo con todos ellos en los que se aceptara la responsabilidad y se asumieran compromisos de futuro por parte del acusado podría jugar algún rol de reparación simbólica con algún efecto atenuante.

De este modo, la justicia restaurativa podría contribuir a la concienciación sobre el daño producido y la restauración de la confianza pública en las relaciones económicas. No obstante, creo que esta reparación simbólica puede

de Dereito da Universidade de Coruña, núm. 1, 1997, pp. 249-251; DE LA HERRÁN, "Aspectos técnicos de la atenuante (...)", ob.cit., p. 26. 94 Vid. DE LA HERRÁN, ult.ob.cit., p. 29. 
desarrollar un papel más importante en la fase de la ejecución de la pena, donde la finalidad prioritaria será la reinserción del condenado, mientras que, en el ámbito de la determinación de la pena, la reparación simbólica, así como la solicitud de perdón, la asunción de responsabilidad y los compromisos de comportamiento futuros sólo pueden jugar un papel complementario de la reparación efectiva del daño.

En suma, en la medida en que la reparación "sustituye" parcialmente la pena, puede exigirse que cumpla con los fines consustanciales al Derecho penal, directamente vinculados con la prevención del delito. Ello pasa por la constatación del personal esfuerzo reparador del reo, que puede existir en casos de reparación parcial, pero que no admite la reparación por tercero, alejando a esta atenuante de la responsabilidad civil ex delito, mucho más objetiva que aquella. En todo caso, la inserción de esta institución en el modelo de justicia restaurativa debería conducir hacia una mayor intervención de la víctima en el diálogo restaurativo, que por supuesto, en los delitos socioeconómicos ha de presentar particularidades acordes con la naturaleza colectiva de la víctima.

\section{Bibliografía}

ALONSO FERNÁNDEZ, J. A., Las atenuantes de confesión de la infracción y reparación o disminución del daño, Bosch, Barcelona, 1999.

ARMENTA DEU T., Lecciones de derecho procesal penal, Marcial Pons, Madrid, 2017.

BARJA DE QUIROGA / RODRÍGUEZ RAMOS / RUIZ DE GORDEJUELA LÓPEZ, Códigos penales españoles 1822-1848-1850-1870-1928-1932-1944. Recopilación y concordancias, Akal, Madrid, 1988.

BAUCELLS LLADÓS, J., "La atenuante de reparación del daño ambiental tras la Ley de responsabilidad ambiental", en Pigrau Solé, A. (Coord.) Nuevas perspectivas 
de la responsabilidad por daños al medio ambiente, Madrid, Ministerio de Medio ambiente, 2006.

BAUCELLS LLADÓS, J., "Sistema de penas para el delincuente económico", en Cuadernos de política criminal, núm. 107, 2012.

BOIX REIG. J., "Reflexiones sobre la reforma del Código Penal en materia de lucha contra el fraude tributario", en Diario La Ley, núm. 7966, 2012.

BRICOLA, F., «Funzione promozionale, tecnica premiale e Diritto Penale», Diritto Premiale e Sistema Penale, Milano, 1983.

CARDENAL MONTRAVETA, S., "La respuesta del derecho penal a los delitos fiscales de Cristiano Ronaldo (y de otros)", en La Ley Penal, núm. 136, 2019.

CASTRO, D./BONSIGNORE, D., "Delincuencia socioeconómica y daño social. Perspectivas político-criminales para un contexto poscrisis", en Estudios Penales y Criminológicos, núm. 40, 2020. https://doi.org/10.15304/ epc. 40.6212

CHOZA CORDERO, A. y RIZO LEON, A., "Reparación del daño en los delitos contra la Hacienda Pública: Atenuante simple o atenuante muy cualificada", en Revista Aranzadi Doctrinal, núm. 4, 2020.

CUGAT MAURI, M./BAÑERES SANTOS, F., "Delitos contra la Hacienda pública y la Seguridad social", en Álvarez García (Dir.), Derecho penal español. Parte especial. II, Tirant lo Blanch, Valencia, 2011.

DE LA HERRÁN, S., "Aspectos técnicos de la atenuante de reparación del daño en los delitos económicos o de cuello blanco", en Revista penal, núm. 45, 2020.

DE VICENTE MARTÍNEZ, R., "Circunstancias de la responsabilidad criminal", en Demetrio Crespo, E. (Coord.), Lecciones y materiales para el estudio de Derecho penal, Tomo II, Teoría del delito, Iustel, Madrid, 2015. 
DE VICENTE REMESAL, J., El comportamiento postdelictivo, León, Servicio de publicaciones de la Universidad de León, 1985.

DOMINGO MONFORTE, J.- PEÑALOSA TORNÉ, C., "La atenuante de reparación del daño. Tratamiento legal y jurisprudencial”, en Diario La Ley, núm. 9615, 2020.

FARALDO CABANA, P., "La aplicación analógica de las atenuantes de comportamiento postdelictivo positivo (los núms. $4^{\circ}$ y $5^{\circ}$ en relación con el núm. $6^{\circ}$ del artículo 21 del Código penal de 1995)", Facultade de Dereito da Universidade de Coruña, núm. 1, 1997.

FERNÁNDEZ PANTOJA, P., "La reparación del daño como respuesta al delito", Estudios Jurídicos Penales y Criminológicos, en Homenaje al Prof. Dr. Dr. H. C. Mult. Lorenzo Morillas Cueva, Suárez López, Barquín Sanz, Benítez Ortuzar, Jiménez Díaz, SainzCantero Caparrós (Dirs.), Dykinson, Madrid, 2018.

GALAIN PALERMO, P., “¿La reparación del daño como «tercera vía» punitiva? Especial consideración a la posición de Claus Roxin", Revista Electrónica de Derecho de la Universidad de La Rioja, núm. 3, 2005. https:// doi.org/10.18172/redur.3862

GALAIN PALERMO, P., La reparación del daño a la víctima del delito, Tirant lo Blanch, Valencia, 2010.

GARCÍA SAN MARTÍN, J., "La reparación del daño como circunstancia modificativa de la responsabilidad criminal", en Revista de Derecho Penal, núm. 32, 2011.

GARCÍA SOLÉ, M./MARTÍ GARCIA-MILÀ, N., "Justicia restaurativa: la circunstancia atenuante del art. 21.5 CP de reparación del daño ocasionado a la víctima", en Lluch, A. (Coord.), Las medidas preventivas de conflictos jurídicos en contextos económicos inestables, Bosch, Barcelona, 2014. https://doi.org/10.2307/j. ctvs09qd3.10 
GARRO CARRERA, E., Atenuantes de reparación y de confesión. Equívocos de la orientación utilitaria (A propósito de una controvertida sentencia del Juzgado de lo penal $n^{\circ} 8$ de Sevilla), Tirant monografías, Valencia, 2008.

GUARDIOLA LAGO, M. ${ }^{\mathrm{a}}$ J., “¿Es posible la justicia restaurativa en la delincuencia de cuello blanco?", en Estudios Penales y Criminológicos, Vol. XL, 2020. https:// doi.org/10.15304/epc.40.6695

IGLESIAS CAPELLAS, J., "La regularización de la defraudación tributaria constitutiva de delito contra la Hacienda Pública", $R C y T, \mathrm{CEF}$, núms. 341-342, 2011.

LÓPEZ FONDÓN, P. y HERNÁNDEZ GARCÍA, J., "Juicio oral (II): práctica y valoración de la prueba", en Cugat Mauri/Baucells Lladós/Aguilar Roma, Manual de litigación penal, Tirant lo Blanch, Valencia, 2017.

MAGRO SERVET, V., "Doctrina jurisprudencial reciente del Tribunal Supremo sobre la atenuante de reparación del daño (art. 21.5 CP)", en La Ley penal, núm. 50, 2008.

MANZANARES, J. L., Mediación, reparación y conciliación en el Derecho Penal, Comares, Granada, 2007.

MARTÍNEZ-BUJÁN PÉREZ, C., en Pérez Álvarez (Ed.), "La expansión, la reducción y la legitimidad del Derecho penal económico", Serta in Memoriam Louk Hulsman, CISE- Ediciones Universidad de Salamanca, 2009.

MORALES PRATS, F. y BERTOLÍN PONSA, E., "Juicio oral (I): artículos de previo pronunciamiento, cuestiones previas e inicio del juicio oral”, en Cugat Mauri/ Baucells Lladós/Aguilar Roma, Manual de litigación penal, Tirant lo Blanch, Valencia, 2017.

MUÑOZ CUESTA, J.C., y otros, "Reparación o disminución del daño causado", en Las circunstancias atenuantes en el Código Penal de 1995, Aranzadi, Pamplona, 1997. 
POZUELO PÉREZ, L., El desistimiento en la tentativa y la conducta postdelictiva, Tirant monografías, Valencia, 2003.

PRATS CANUT, M.-MARQUÉS I BANQUÉ, M., Comentarios al Nuevo Código Penal, Quintero Olivares, G. (Dir.), Aranzadi, Pamplona, 2004.

PUENTE ABA, M. , "La reparación en el marco del derecho Medioambiental", en Anuario da Facultade de Dereito da Universidade da Coruña, núm. 8, 2004.

QUINTERO OLIVARES, G., "La responsabilidad civil y la reparación en la política criminal contemporánea", en Responsabilidad civil ex delicto. Cuadernos de Derecho Judicial, Madrid, 2005.

QUINTERO OLIVARES, G., "El castigo de la delincuencia económica y el riesgo de derecho penal de autor", en Liber Amicorum, Estudios Jurídicos en Homenaje al Prof. Dr. Dr. h. c. Juan M. ${ }^{a}$. Terradillos Basoco, Tirant lo Blanch, Valencia, 2018.

RAMOS MENDEZ, F., Enjuiciamiento Criminal. Duodécima lectura constitucional, Atelier, Barcelona, 2016.

REBOLLO VARGAS, R./CASAS HERVILLA, J., "El proceso penal y la investigación de la delincuencia económica", en García Arán, M. (Dir.), La delincuencia económica. Prevenir y sancionar, Tirant lo Blanch, Valencia, 2014.

ROXIN, C., "Pena y reparación", en ADPCP, Vol. LII, 1999.

SILVA SÁNCHEZ, J.M., Delitos contra el medio ambiente, Tirant lo Blanch, Valencia, 1999.

SOLETO, H.-GRANÉ, A., La reparación económica de la víctima en el sistema de justicia, Dykinson, Madrid, 2019.

SOTO NIETO, F., "Atenuante de reparación o disminución de los efectos del delito", en Diario La Ley, núm. 6609, 2006.

TAMARIT SUMALLA, J. M. a " "La difícil asunción de la reparación penal por parte de la jurisprudencia española", en Revista General de Derecho Penal, núm. 7, 2007. 
TAMARIT SUMALLA, J. M. a, "La justicia restaurativa: concepto, principios, investigación y marco teórico", en Tamarit Sumalla (Coord.), La justicia restaurativa: desarrollo y aplicaciones, Comares, Granada, 2012.

VIDALES RODRÍGUEZ, C., "Derecho penal del amigo (Reflexiones críticas acerca de la reciente modificación de los delitos contra la Hacienda Pública y la Seguridad Social)", en Revista de derecho y proceso penal, núm. 32, 2013.

VIDALES RODRÍGUEZ, C., "La reparación del daño en los delitos relativos a la ordenación del territorio y la protección del patrimonio histórico y del medio ambiente. Análisis del artículo 340 del Código Penal", en Estudios de Derecho Ambiental. Libro Homenaje al profesor Josep Miquel Prats Canut, Quintero Olivares, G.-Morales Prats, F. (Coord.), Tirant lo Blanch, Valencia, 2008. 